\title{
The occupation of trawl fishing and the medical aid available to the Grimsby deep sea fisherman ${ }^{1}$
}

\author{
S. R. W. MOORE ${ }^{2}$ \\ The Health Department, Kingston upon Hull
}

Moore, S. R. W. (1969). Brit. J. industr. Med., 26, 1-24. The occupation of trawl fishing and the medical aid available to the Grimsby deep sea fisherman. The mortality of fishermen is twice that of coalminers. Because of the method of fishing the mortality of the trawlerman is probably higher. Outside the industry little is known about the occupation of trawl fishing. Its size, the number of men employed, and the number and distribution of trawlers are therefore described, with particular reference to the port of Grimsby. As near, middle, and deep water trawlers sail from Grimsby, its industry gives a good representation of conditions in the industry as a whole. The port and the fishing grounds are described.

The composition of the trawler crew, their conditions of work, accommodation, and remuneration are explained. A description is given of the trawl apparatus, fishing operations, and the hazards involved, and extracts from the writer's diary of a fishing voyage are appended.

The United Kingdom has ratified the Accommodation of Crews (Fishermen) Convention 1966 of the International Labour Organisation, and an informal survey of a modern trawler fleet showed that it fell short of the requirements of this Convention. Accommodation is confined and the crew live and work in close proximity and in conditions of physical discomfort.

Trawlermen work for long hours under conditions which would not be tolerated by the shore worker. The method of payment is such that trawlermen may take unnecessary risks. Earnings depend on team work so that illness and injury are often not reported with consequent deterioration of the condition.

Physical fatigue and lack of sleep contribute to an increased accident rate. It is therefore recommended that more men per trawler should be employed to allow shorter working hours. As the skipper and mate are paid wholly on a share basis, the remainder of the crew receiving, in addition, a basic wage, it 'pays' the trawlermen to take risks. A different method of payment, not dependent on the yield of the voyage, is therefore recommended.

The medical aid available to trawlermen is described and is usually by radio link with shore or a ship with a doctor on board. Although the skipper has some training in first aid and may use The Ship Captain's Medical Guide and the contents of the medicine chest, it is shown that most skippers prefer the radio link or to put into port for medical assistance. In 1963, 165 Grimsby trawlermen were put ashore.

The medical aid given to 120 trawlermen by the Icelandic patrol of the Fishery Protection Squadron is described. Diagnosis and treatment by radio-telephone was difficult and not always successful and medical officers boarded trawlers whenever possible.

\footnotetext{
1The material in this paper formed part of an M.D. thesis submitted to Queen's University, Belfast.
}

${ }^{2}$ Now Medical Officer of Health and Principal School Medical Officer, City of York. 
Squadron patrols are irregular. Medical officers would be fully occupied in the treatment of trawlermen if there were regular patrolling of the fishing grounds.

In comparing the records of the medical officers of the Fishery Protection Squadron with those of skippers in the trawler log books, it was discovered that less than half the incidents were recorded by skippers and there were fewer illnesses than injuries. A retrospective study using only the Official Trawler Log Book as a basis of information will therefore give a low estimation of the morbidity due to injury and especially to illness.

As the treatment of trawlermen at sea is haphazard and depends on the knowledge of first aid of individual skippers, and as it is often delayed, there should be greater emphasis on the teaching of first aid and the use of The Ship Captain's Medical Guide. As many trawlermen are put ashore for medical treatment, ports in the vicinity of the fishing grounds should be surveyed to ascertain what medical facilities are available and skippers should be advised which ones are best suited to assist them.

Deep sea trawling is a dangerous and extreme occupation (Tunstall, 1962; Schilling, 1966). This has always been recognized within the industry and until recently death and serious injury have been accepted by deep sea fishermen as part and parcel of the job of trawling. This fatalistic attitude has extended to trawler owners and even to members of the medical profession.

Schilling (1966) has shown that fishermen's fatal accident rates at sea are about twice the rates for coalminers and about 20 times the rates for the manufacturing industries, and they may be higher. In the most recent Registrar General's Decennial Supplement on Occupational Mortality for the years 1949-53 (Registrar General, 1958), the Standardized Mortality Ratio for fishermen for Other Accidents (which includes all accidents other than motor accidents - S.M.R. 50, and accidents in the home S.M.R. Nil) is 336 , more than three times the rate for all males. The Registrar General commented, "As might be expected from the hazardous nature of their occupation, deaths from "other accidents" were more frequent than in the average male population'. Deaths at sea are recorded separately by the Registrar General of Shipping and Seamen and are not included in the above figure. The S.M.R. therefore underestimates the total accident risk among fishermen. As trawling is considered to be the most dangerous method of fishing it may be assumed that the rates and ratios for trawlermen will be greater than for all fishermen.

\section{Review of the relevant literature}

There is comparatively little in the medical literature about the mortality and morbidity of fishermen and still less about that of trawlermen.

In 1930, Heijermans described different types of fishing and covered such aspects as crew accommodation, hygiene, and health statistics. He dealt with conditions in the industry then existing, which have largely disappeared at the present time. Sailing boats were still in use and he compared conditions on board with those on the newer steam boats. Crews' quarters in the forecastle were poorly ventilated and heated by coal stoves. Ships' equipment was stored in the quarters and food was cooked there. Lighting was by candles and oil lamps. There was no wash place, sanitary accommodation was usually lacking, and buckets were used for both needs. Straw mattresses were preferred as they were cheap and easily disinfected and could be thrown overboard if infested on return to port. In the period 1921-23 in Great Britain, of 24,485 persons employed as fishermen, $630(2.57 \%)$ died. French statistics indicated that of 14,218 men engaged in large-scale fishing, $352(2.47 \%)$ died during voyages 'which lasted six months'. It was noted that the sequelae of disease and accidents were often more serious because of lack of medical care at the outset and the long distances that had to be covered to reach medical aid.

Also in the 'thirties, Shambaugh (1935) commented on the high incidence of tar cancer of the lip in the fishermen of Massachusetts in the United States of America. He pointed out that tar, used on nets to prevent their rotting, was transferred to the lips by the wooden needle used by fishermen and suggested that this might be the cause of the cancer.

There have been two papers by medical officers of the Fishery Protection Squadron of the Royal Navy. Bowdler (1954) described the duties of the Squadron, noting that one of them, medical attention to deep sea fishermen, was most welcomed by trawler skippers. He compared his own experience on the Icelandic fishing grounds with that of a doctor in a German hospital ship on the same grounds, 'A fairly wide spectrum of cases was met with', but these were not described. He made a plea that specially designed and equipped ships should be provided for fishery protection patrolling.

Millar (1959) also described the medical officer's experiences, with special reference to the transfer of patients and the medical officer between H.M. 
Ship and trawlers. The use of the life raft was advocated in all but the heaviest seas and the technique was described in detail. The paper ended with a short note on the variety of patients encountered 'the majority of whom are suffering from the effects of trauma'.

In 1954, MacQueen described some aspects of the health of trawlermen of the Aberdeen fleet. He commented that 'No one has hitherto apparently thought it worthwhile seriously to investigate any aspects of the health of trawl fishermen', and he had limited himself to 'the most easily ascertained forms of disability, accidents, injuries and a few dermatological conditions'. He compared injuries which occurred in 1912 with those of a period in late 1952 to early 1953 but gave little statistical information. Septic fingers and hands, and other finger and hand injuries, were the most frequent lesions. 'Investigation is difficult and legal powers are far from adequate. Any medical officer seeking to study the subject will find it imperative to gain and keep the co-operation and good will of the owners and men, and for various reasons the co-operation is not easy to obtain'.

The following year Burns (1955) described the medical problems of deep sea trawling as seen from his 25 years' experience as medical officer to trawlermen in Hull. He gave a history of trawl fishing and described the setting up of the medical service in Hull. Septic infections and crushing injuries were commonly seen at the outset and crushing injuries were still the greatest hazard. No statistical information on morbidity or mortality was given in this paper.

Two papers from the Institute of Marine Medicine in Gdańsk were concerned with Polish fishermen on base ships and smaller fishing boats in the North Sea. The first (Ejsmont, 1958) gave an account of illnesses of trawlermen attended in 1958 by doctors on base vessels, which operated for periods of four to six weeks from April to December serving a flotilla of 100-130 fishing boats. The conditions of work and climate and the injuries and illnesses that occurred were described. One thousand five hundred fishermen received medical attention. Of the consultations $22 \%$ were for injuries and $21 \%$ for skin complaints. Complaints of pains in the muscles and joints were dominant among the crews of fishing boats, both for deck and engine room crew. There was a higher percentage of illness of the circulatory system and the alimentary tract in engine room personnel.

Ejsmont and Szczeblewski (1959) gave an evaluation of the nutrition of fishermen on a base vessel also operating in the North Sea in July and August 1954. The composition of the crew and the method of investigation were described. Two hundred and twelve persons on board were examined, special attention being paid to the state of the teeth, blood morphology, and the amount of ascorbic acid in the urine. The authors concluded that the standard of nutrition on the base vessel was characterized by a very high caloric value arising from an excess of fats and albumen and low quantities of carbohydrates in the form of fruit and vegetables. In general, the nourishment of the crew was good, only some deficiency in vitamin $\mathrm{C}$ being observed. The crew's teeth were found to be in a bad state, indicating the need for an increase in the amount of fruit and vegetables in the diet.

In the account by Friemann, Overhoff, and Wolter (1959) of eye diseases in the fishing industries, the workers concerned were employed in fishing for and landing immature herrings and eels. The eye diseases ranged from transitory conjunctivitis to severe keratitis with permanent loss of vision, and were caused primarily by the spray from wet and partially decomposed fish during landing. It was recommended that workers should wear goggles and that skilled ophthalmic care should be immediately available.

In 1959 Goethe, Rinck, and Gudmundsson gave an account of the medical care provided for German fishermen by two hospital ships for the years 1950-55. The fishermen worked from cutters, luggers, and steam fishing vessels. The information was derived from the medical records of the personnel treated. Accidents accounted for most of the disability on the fishing vessels followed by septic infections of the hand and diseases of the teeth, mouth, and jaw and of the digestive tract. The dental state of nearly 500 luggermen was described and it was suggested that the gingivitis and periodontal infection present were probably due to poor dental hygiene, excessive use of tobacco, and insufficient vitamin $\mathrm{C}$ in the diet.

Grant (1961), writing from Aberdeen, developed the idea that the term 'fisherman' means nothing, as there are many kinds of fishermen, ranging from the crofters in the remote parts of Scotland and part-time fishermen to the deep sea fishermen or trawlermen. He discussed the medical problems of fishermen, some social characteristics, and the difficulties in carrying out a study. He compared the morbidity in a group of trawlermen with that in a group of dock labourers, with special reference to peptic ulceration, and concluded that the morbidity in Aberdeen trawlermen was artificially low because the unfit leave the sea, and that there was more peptic ulceration in dock labourers than in trawlermen. He interviewed 30 trawlermen and all agreed that septic skin conditions caused most trouble. He catalogued 60 injuries and 17 illnesses as logged in $71 \log$ books of Aberdeen trawlers. Slips and falls caused most injuries, and hands, wrists, and fingers were most often injured. Referring to gastric ulceration and carcinoma, he concluded that 'there 
is a "prima facie" case for investigating the morbidity and mortality of a strictly defined group of fishermen of known economic and cultural status'.

The Fishermen by Jeremy Tunstall, published in 1962 , is a sociological study of the deep sea fishermen of Hull and throws light on many aspects of the fisherman's life at sea and ashore which are relevant to his health.

Tunstall noted that the deep sea fisherman's occupation is 'extreme from a number of different points of view. The job is extreme in danger, the death rate being higher than in coal-mining; moreover trawler fishermen in the two world wars have had a casualty rate equalled by few occupations. The job, especially in winter, is carried on in extreme conditions, as these trawlers fish off the coasts of Iceland, Russia, and Greenland. The job is extreme in the number of hours worked; at the fishing grounds deckhands can be on duty for 180 hours in 10 days of active fishing; deck learners, who may be no more than 16 years old, nevertheless also do 18 hours' work a day for 10 days in succession. The job is extreme from the point of view both of unusually high and unusually low rates of earnings. About half the Hull trawler skippers, although they left school at 14, make $£ 5,000$ a year; on the other hand, if ascending rates of overtime pay are calculated, trawler deckhands average as little as 3s. 6d. per hour, and can be said to be probably the lowest paid workers in any British industry'.

Leiper (1966) described briefly the trawl fishing industry and the work of trawlermen, and discussed their injuries and illnesses and the provision of medical care. He compared the incidence of injuries occurring in 1912 with those of 1957. In the latter year, most injuries were to the back and shoulder, followed by septic fingers and hands, other finger and hand injuries, and leg and foot injuries. Little statistical information is given. He noted that the medical literature was scant, in sharp contrast to that on men of the Royal Navy. 'The epidemiology of the illnesses of fishermen has yet to be written.'

From time to time deep sea fishermen are affected by a condition they call 'Dogger Bank Itch'. From an examination of 451 trawlermen from Lowestoft, Newhouse (1966) concluded that the itch was an allergic dermatitis due to contact with a sea-weedlike organism, the Alcyonidium gelatinosum. Thirtytwo men $(7.1 \%)$ were affected, the prevalence being highest among mates. Other occupational skin diseases were described and advice was given on improved protective clothing.

Schilling (1966) gave an account of trawl fishing and the nature and hours of work. He discussed the accident risk, the mortality of fishermen (twice that of coalminers), and the sources and inaccuracy of mortality statistics. He noted that there was little information about sickness experience and that there was difficulty in estimating the population at risk. Statutory measures for protecting the health of fishermen in Great Britain are minimal. He suggested that one of the first essentials was to have a better system of recording and investigating both fatal and non-fatal accidents, and that one Ministry should be responsible for health and safety in the fishing industry. ${ }^{1}$

\section{Trawl fishing}

The four main methods by which fish are caught commercially are lining, drifting, seining, and trawling. Trawling, because of its efficiency, is by far the most common method, catching demersal fish, such as cod and haddock, which live on the sea bed, and $70 \%$ by weight and $75 \%$ by value of the total fish catch is obtained in this way by deep sea fishermen.

When the fishing nations of the world are listed according to the amount of fish landed in 1965 , the United Kingdom with $1,046,800$ metric tons is the eleventh largest (Food and Agricultural Organisation of the United Nations, 1966). Of European countries, the United Kingdom is third to Norway and Spain.

In 1965, 493,200 tons of white fish, valued at $£ 39,708,000$, were landed in England and Wales by British vessels, of which 166,252 tons of demersal fish valued at $£ 14,367,841$ were landed at Grimsby (Ministry of Agriculture, Fisheries and Food, 1967a).

Although Grimsby ships fished off Iceland in the 15th century (Gillett, 1965), the earliest recorded trawling was by the Dutch in the 17th century (Tunstall, 1962). In the early 19th century, the trawl net was towed along the sea bed by sailing vessels, its mouth being held open by a wooden beam.

In 1843, a very rich fishing ground was discovered 60 miles from the mouth of the Humber. It became known as the Silver Pit and is part of the Dogger Bank. This discovery coincided with the expansion of the railways and, with links to London, Lancashire, and the Midlands, there followed the spectacular growth of the fishing industries of Grimsby and Hull.

The conventional trawler preserves its catch by stowing it on ice, limiting the duration of the voyage, and covering the distance to port in the fastest possible time. It has, however, three main disadvantages. As the net is shot (put overboard into the sea) and hauled (returned to the ship) over the ship's side, the trawler must turn broadside on to

\footnotetext{
${ }^{1}$ The writer found the sociological study of Hull trawlermen by Tunstall (1962) of more value than any of the publications in the medical literature until Professor Schilling's searching paper (1966). Most of the writer's research had taken place between the years of Tunstall's and Schilling's studies (196366) when there was an absence of medical comment on the health of fishermen.
} 
the wind (vide infra) and therefore fishing has to be abandoned in bad weather. Secondly, it spends half the voyage getting to and from the fishing grounds. Thirdly, only half the horsepower necessary for steaming is required for trawling. 'The modern trawler with its high capital cost and complex and expensive equipment is about as costly a vehicle for transporting fish from the catching grounds to port as can be devised: the modern trawler is designed as a draft horse and race horse in one, and required to commute at a gallop between its stable and place of work' (Ministry of Agriculture Fleck Committee Report, 1961).

More recently, the stern trawler has made its appearance. The first in the world sailed from Grimsby (Cooper, 1965). In this ship the net is shot and hauled over the stern along a ramp, as in a whaling ship, the ship heading into the wind. More mechanical aid is possible than in the conventional trawler. It costs about $10 \%$ more, but operation costs are less and a smaller crew can man the vessel.

\section{The port of Grimsby}

The County Borough of Grimsby is the largest town in Lincolnshire with a population of 96,780 . It is situated on the south bank of the River Humber, only six miles from its mouth at Spurn Head, and is adjoined on the south and east by the seaside resort of Cleethorpes, making with it one conurbation of 129,480 inhabitants.

The fishing industry forms as a unit the largest single employer of labour in the town. Thousands are employed, not only as fishermen but also in associated industries such as ship repairing, engineering, and fish processing.

Over 3,000 men go to sea as fishermen. Grimsby differs from other ports in the number of varieties of fish landed.

The number of British vessels landing fish at Grimsby varies between 300 and 550 per month, reaching a peak in July and September, while the number of foreign vessels remains fairly steady at between 50 and 120 per month.

\section{The fishing grounds}

Trawlers range over a tremendous area in quest of fish. The area is bounded in the west by the Davis Strait (Fig. 1), in the north by Spitzbergen, in the east by Novayazemlya, and in the south by the Bay of Biscay. Fishing is not carried out everywhere within these limits as trawling is restricted by various circumstances, $e . g$., the depth and nature of the sea bed. Fishing vessels concentrate on localities where ledges and banks on the sea bed render the area suitable for trawling and where fish are known habitually to assemble (Syme, 1966).
Deep sea trawlers can be divided into three main types, depending on the areas in which they operate - distant, middle, and near water trawlers.

Distant water trawlers operate in waters officially delimited as those outside $63^{\circ}$ North latitude, $17^{\circ}$ West longitude, and $43^{\circ}$ North latitude, i.e., in the Barents Sea, around Bear Island and Iceland, and off the coasts of north Norway and south-west Greenland and Newfoundland (White Fish Authority, 1959). Slightly more than half the white fish caught by quantity and slightly less than half on first sale value comes from these waters (Ministry of Agriculture Fleck Committee Report, 1961).

Distant water trawlers brave some of the world's most perilous seas and violent weather in their search for fish. Weather conditions are severe and often hazardous, as demonstrated by the loss of three Hull trawlers early in 1968 . Freezing temperatures, when the deck and rigging of trawlers may be coated with tons of ice, and gales lasting days on end add to the trawlerman's difficulties. For the six winter months of the year fishing takes place in continuous darkness.

Trawling in Greenland waters is seasonal. It is impracticable during the winter months because of the very low temperatures experienced, which cause ice to form so rapidly and in such amounts that it creates great difficulty for those handling the trawl.

Middle waters are those around the Faeroes and Rockall and the continental shelf to the west and north of Scotland (Fig. 1). The North Sea, English Channel, the Minch, and Western Approaches are known as near waters. Although not exposed to the Arctic temperatures and long winters, the middle and near water trawlers have to endure gales which may be just as severe.

The extension of the fishing limits to 12 miles from coasts means that trawlers must go still farther afield in search of fish.

Trawlers are also classified according to their length, and not by weight as are other sea-going vessels. The near water trawler is approximately 80 feet or over, but under 110 feet in length and weighs $200-250$ tons. The middle water trawler is 110 feet and over but under 140 feet in length and weighs 400-550 tons approximately. The distant water trawler is over 140 feet in length but most of the present fleet of vessels sailing from the United Kingdom are over 160 feet and the more recently built vessels are in the 180-200 feet range, weighing 550-750 tons with some up to approximately 1,000 tons. However, vessels in favourable weather often fish outside the waters for which they were designed, the middle water trawlers, for example, making trips in summer weather to the Icelandic fishing grounds.

Distant water trawlers are at sea on an average of three weeks per trip (a round trip could be anything up to 4,000 miles (Fig. 1)). Middle water trawlers 


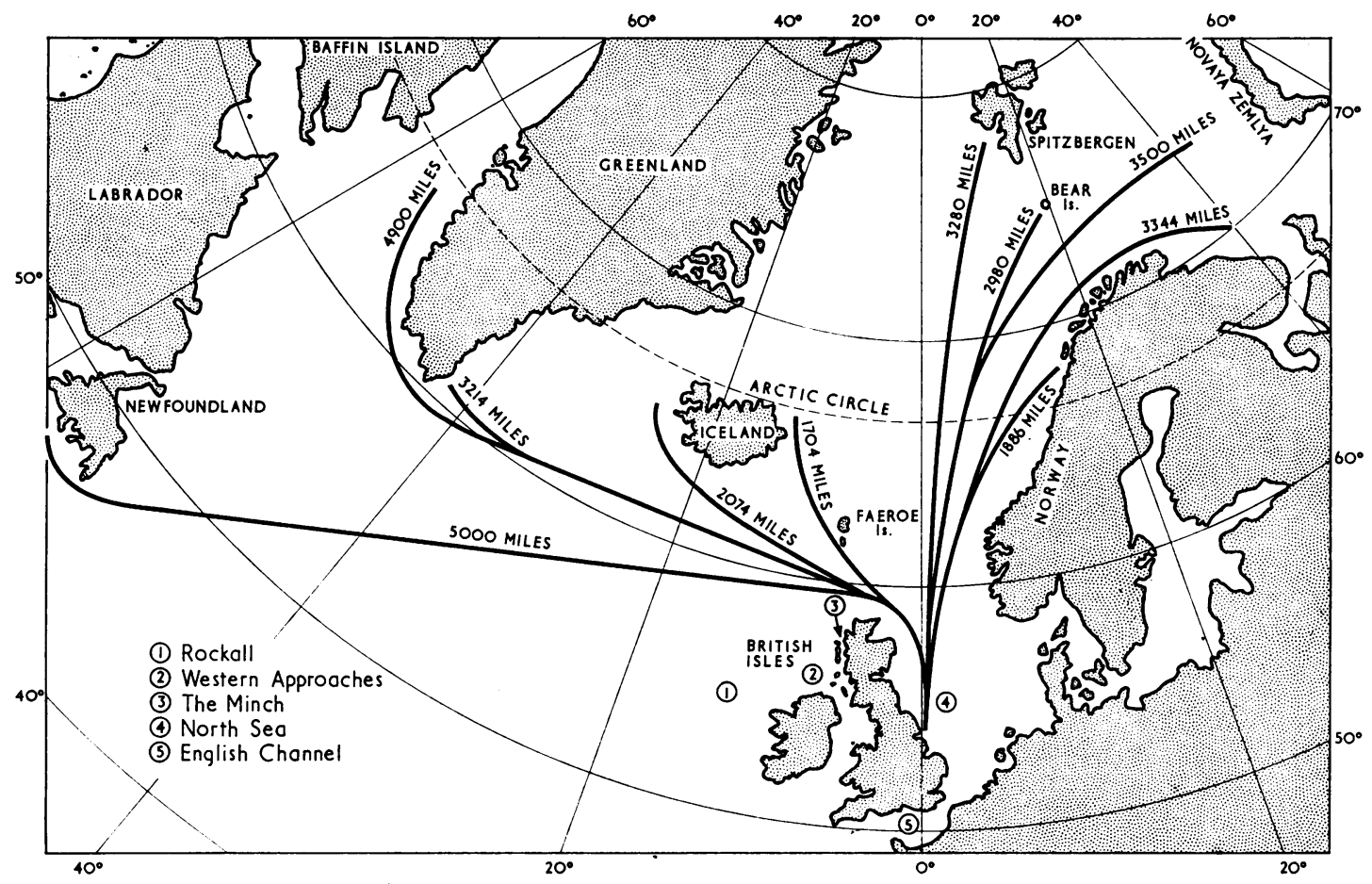

FIG. 1. The fishing grounds (distances in nautical miles).

take up to two weeks, e.g., to the Faeroes and back. Near water trawlers may make trips of only a few days but are usually at sea for at least 10 days.

\section{Number and distribution of trawlers}

At December 31, 1965, 467 trawlers were operating from England and Wales, and during the year a total of $145(21.7 \%)$ trawlers were sailing from Grimsby. Their distribution between near, middle, and distant waters is shown in Table 1. The number of steam and motor vessels in each category is also shown.
The distribution of the trawlers by ports in England, Wales, and Scotland at the end of 1965 is shown in Table 2. It will be seen that more trawlers operated from Grimsby than from any other port. Hull had more distant water trawlers than Grimsby, and Lowestoft more near water trawlers.

The distant water fleet is based almost entirely on Hull and Grimsby.

\section{Number of trawlermen in the industry}

The estimated number of deep sea fishermen in

TABLE 1

Number of Trawlers operating from England and Wales and the Port of Grimsby at DECEMBER 31, 1965

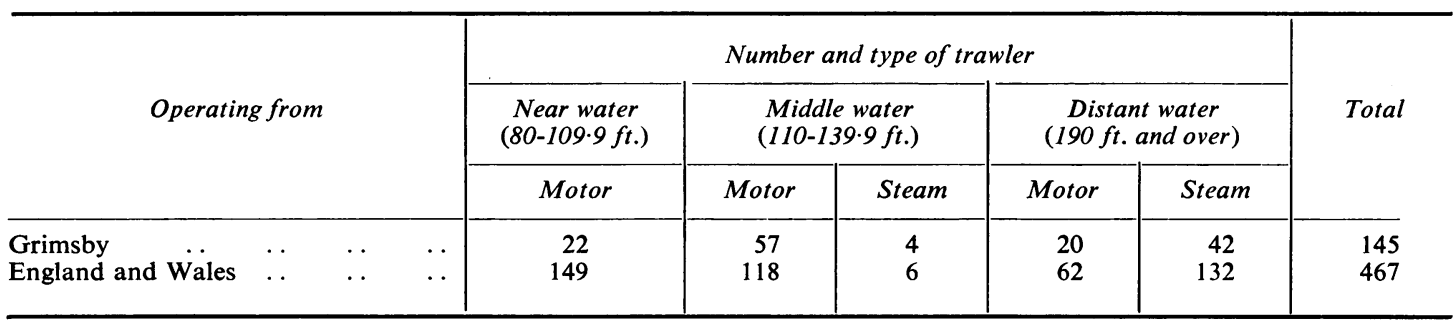

Adapted from Table 12, Sea Fisheries Statistical Tables 1965, Ministry of Agriculture, Fisheries and Food; H.M.S.O. 
TABLE 2

Distribution by Ports in England, Wales and Scotland of Trawlers of 80 fT. AND over Registered Length, AT DeCEMBer 31, 1965

\begin{tabular}{|c|c|c|c|c|c|c|c|c|}
\hline \multicolumn{5}{|c|}{ Port } & $\begin{array}{c}\text { Near water }{ }^{1} \\
(80-109 \cdot 9 \mathrm{ft})\end{array}$ & $\begin{array}{l}\text { Middle water } \\
\text { (110-139.9 ft.) }\end{array}$ & $\begin{array}{c}\text { Distant water }{ }^{2} \\
\text { (140 ft. and over) }\end{array}$ & Total \\
\hline $\begin{array}{l}\text { North Shields } \\
\text { Hartlepool } \\
\text { Hull .. } \\
\text { Immingham } \\
\text { Grimsby } \\
\text { Lowestoft } \\
\text { Brixham } \\
\text { Newlyn .. } \\
\text { Milford Haven } \\
\text { Fleetwood } \\
\text { Granton } \\
\text { Aberdeen }\end{array}$ & $\begin{array}{l}\ldots \\
\ldots \\
\ldots \\
\ldots \\
\ldots \\
\ldots \\
\ldots \\
\ldots \\
\ldots \\
\ldots \\
\ldots \\
\ldots\end{array}$ & $\begin{array}{l}\ldots \\
\ldots \\
\cdots \\
\ldots \\
\cdots \\
\ldots \\
\cdots \\
\ldots \\
\ldots \\
\cdots \\
\cdots \\
\cdots\end{array}$ & $\begin{array}{l}\cdots \\
\cdots \\
\cdots \\
\cdots \\
\cdots \\
\cdots \\
\cdots \\
\cdots \\
\cdots \\
\cdots \\
\cdots \\
\cdots\end{array}$ & $\begin{array}{l}\cdots \\
\cdots \\
\cdots \\
\cdots \\
\cdots \\
\cdots \\
\cdots \\
\cdots \\
\cdots \\
\cdots \\
\cdots \\
\cdots\end{array}$ & $\begin{array}{r}2 \\
3 \\
- \\
22 \\
106 \\
1 \\
4 \\
22 \\
8 \\
11 \\
50\end{array}$ & $\begin{array}{r}6 \\
1 \\
61 \\
10 \\
- \\
5 \\
40 \\
7 \\
62\end{array}$ & $\begin{array}{r}1 \\
116 \\
1 \\
62 \\
1 \\
- \\
- \\
\frac{13}{2}\end{array}$ & $\begin{array}{r}9 \\
3 \\
117 \\
1 \\
145 \\
117 \\
1 \\
4 \\
27 \\
61 \\
18 \\
114\end{array}$ \\
\hline Total & . & $\cdots$ & $\cdots$ & . & 229 & 192 & 196 & 617 \\
\hline
\end{tabular}

${ }^{1}$ Includes 7 great liners. ${ }^{2}$ Includes 3 factory trawlers.

From Appendix III: White Fish Authority Annual Report \& Accounts, 1966.

TABLE 3

England and Wales - Deep Sea Fishermen: Estimated Numbers Employed in Sea Fishing IN 1936 AND 1961-66 (AT DeCEMBER 31 OF EACH YeAR)

\begin{tabular}{c|c|c|c}
\hline Year & $\begin{array}{c}\text { Regularly } \\
\text { employed }\end{array}$ & $\begin{array}{c}\text { Occasionally } \\
\text { employed }\end{array}$ & Total \\
\cline { 2 - 3 } 1936 & 19,261 & 1,269 & 20,530 \\
1961 & 10,009 & 251 & 10,260 \\
1962 & 9,686 & 175 & 9,861 \\
1963 & 9,072 & 186 & 9,258 \\
1964 & 8,526 & 155 & 8,681 \\
1965 & 8,030 & 155 & 8,185 \\
1966 & 7,507 & 145 & 7,652 \\
\hline
\end{tabular}

Personal communication with the Secretary, Ministry of Agriculture, Fisheries and Food, 1967b. The 1936 figure includes a small number of inshore fishermen, as returns in that year did not show the breakdown to inshore and deep sea fishermen, as is the practice of recent years.

regular and occasional employment in 1936 and the years 1961-66 is shown in Table 3. The number of deep sea fishermen regularly employed in 1966 was less than half that in 1936. The fall in the total number of fishermen reflects the contraction in size of the fishing fleet over the years. The more efficient trawlers of today, operating with smaller crews, bring home a proportionately higher catch per vessel.

\section{The crew}

The number of persons carried by the deep sea trawler sailing from Grimsby depends on its size and the sea area in which it operates. Near and middle water trawlers carry 10 to 14 men whereas the larger middle and the distant water trawlers carry up to 20 men.

All Grimsby vessels carry a skipper, mate, and third hand, a chief and second engineer, a cook, and usually a deck learner. Distant water trawlers carry in addition two firemen, a galley boy, and a radio operator. The crew complement is made up of deck hands. One or two of the deck hands may be designated deck trimmers in the trawler log book, but the duties of deck hand and deck trimmer are interchangeable. Any vessel may carry, in addition, a trainee engineer, but he usually sails on the distant water trawler.

The skipper, mate, and third hand, the chief and second engineer, the cook, and the radio operator are officers and they have separate mess and toilet facilities and sleeping accommodation.

The skipper The skipper is a certified officer, having taken the certificate of competency issued by the Ministry of Transport. He is chosen by the vessel owner, whose wishes he must know and whose confidence he must retain. He must hold his crew together as a contented body of men and have a full knowledge of the duties of each member of his crew. This he has gained in his promotion from the deck, having most likely entered the industry as a deck learner. On his way to the top, he will have been deck hand, third hand, and mate.

The mate The mate is second in command. $\mathrm{He}$ is responsible for preparing and stowing the catch, for its preservation throughout the trip, and its 
landing on reaching port. He is the second of the two certified officers required by Ministry of Transport regulations on all fishing vessels of $\mathbf{5 0}$ tons weight or over, the other being the skipper. The mate is the deck foreman in charge of deck operations such as shooting and hauling the nets. Between hauls he supervises in the fish rooms below decks.

The third hand In ships sailing from ports other than Grimsby the third hand is also known as the boatswain. He is next in seniority to the mate and stands in for him when he is off watch. His chief responsibility is the care of the cod-end of the net (the terminal section which takes the weight of the fish) (Figs 2 and 9). He releases the fish from the cod-end onto the deck and secures it again, using a special knot. When the nets have gone over the side he joins, and takes charge of, the deck hands in the gutting of fish. He takes his turn on the bridge to relieve the skipper or mate.

The deck hand (deck trimmer) The deck hand is the equivalent of the seaman on a merchant ship. On the grounds he is one of the working team, made up of other deck hands, the deck learner, third hand and mate, which shoots and hauls the gear. He guts the fish for stowing. He may, instead of gutting, go below with the mate to the fish rooms to break up ice and stow the fish between layers of ice. In some vessels a deck hand who does this work may be designated a deck trimmer. Signed on as such, he will work in the fish room for the whole of that voyage.

The deck learner The deck learner is the youngest member of the deck team. He may join the ship at the age of 16 to assist the deck hands in their work.

Engineers and firemen (greasers) Every trawler carries a chief and second engineer, and the distant water trawler has, additionally, two firemen. The engineer, chief or second, is not a certified officer as recognized by the Ministry of Transport and there- fore may not man ships other than fishing vessels.

The term 'fireman' comes down from pre-war days when his main job was stoking the boilers on coal-burning trawlers. His opposite number on the modern diesel vessel is called a greaser.

Trainee engineer A trainee is usually an engineer from a steam trawler gaining diesel experience prior to transfer to a diesel vessel. He is a crew member in addition to the two engineers and the two firemen.

Cook and galley boy All vessels carry a cook. He must provide three square meals a day. He is a key man on board a trawler as good cooking boosts the morale of the whole crew.

Distant water trawlers also carry a galley boy, who assists the cook in catering for the larger crew. $\mathrm{He}$ is usually the youngest member of the crew and may sign on at the age of 15 . He serves the meals and does the chores. He may wish to become a cook or he may sail as a galley boy until he is old enough to transfer to the deck as a deck learner. Older men also go to sea as galley boys (sometimes known as assistant cooks) for many years of their lives.

Radio operator The radio operator is carried only on distant water trawlers, as near and middle water trawlers use the radio telephonic link with shore stations. Most radio operators (approximately 75\% in Grimsby) are employed by the trawler owners. The remainder are employed by the firms which manufacture the equipment used. This equipment is on hire to the trawler owners.

\section{Conditions and hours of work}

The conditions of work depend to some degree on the age of the vessel. The owners pick the top and most skilled skippers for their newest craft These are the men who consistently bring home large catches of high value. Consequently, fishermen clamour to sail with the top skippers on the newer vessels. The skipper has his choice of men and can pick and choose who will make up his crew. Conditions will be relatively pleasant on such a ship,

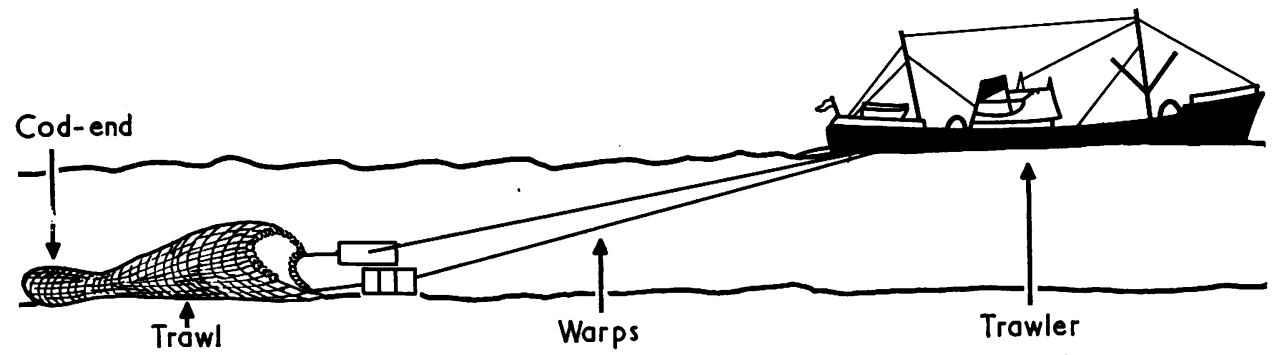

FIG. 2. The trawl in tow. 
although the work is no less hard. The crew will consist of the best of fishermen, in good physical trim and in the younger age groups.

Older ships will get skippers who are not so good. The earning power of such ships will be lower and they will attract either older or less skilful men. The fishermen on such a vessel will work with less upto-date equipment and live in poorer surroundings.

The skipper At sea, the skipper spends most of his time on the bridge. His quarters are close by and he seldom leaves the bridge or his quarters except for meals. Some skippers will even have meals brought to the bridge.

On the outward journey to the fishing grounds he alternates watches with the mate and third hand. His watch is often taken by an experienced deck hand whom he supervises. It is usually a daytime watch so that he gets his full quota of sleep and thus conserves his energy for fishing. However, where there is difficult navigation, a crowded shipping lane, or bad weather, he is on the bridge whatever the hour.

On the grounds, fishing continues throughout the 24 hours for 8 to 12 days. The skipper is then on duty almost continuously, manoeuvring his ship, shooting and hauling nets, regulating their depth, and following the contours of the sea bed. Most skippers will have 6 hours' rest in 24, arranging sleep so as to be available for shooting the nets and setting the course of the next trawl. However, some skippers, especially if fishing is good, snatch only a few hours' sleep in 24 and may not undress for days.

Deckmen The outward journey for the deckmen is relatively easy. The ship is prepared for fishing. The fishing gear is assembled and the nets are checked and fitted to the bobbins. Deck lights are secured for night fishing. All hands assist in this preparation.

The times of watches on Grimsby trawlers are as follows:

$$
\begin{array}{rr}
1 & 7.30 \text { a.m. }-12.30 \text { p.m. } \\
2 & 12.30 \text { p.m. }-6.30 \text { p.m. } \\
3 & 6.30 \text { p.m. }-11.00 \text { p.m. } \\
4 & 11.00 \text { p.m. }-3.00 \text { a.m. } \\
5 & 3.00 \text { a.m. }-7.30 \text { a.m. }
\end{array}
$$

On distant water trawlers the watches are taken by the mate, third hand, and the most experienced deck hand (the skipper's watch), accompanied respectively by two deck hands. Each is on duty therefore every third watch. The remainder of the deckmen, usually three or four, depending on the total number of the crew, are known as day men. They work from 8.30 a.m. to 6.0 p.m. every day, preparing nets and gear and doing various odd jobs.
Extra assistance, if required, is drawn from the men on watch. On near and middle water trawlers watches are taken in the same manner except that, because of the smaller crew, only one deck hand accompanies the mate, third hand or experienced deck hand.

On the fishing grounds, however, work is continuous, shooting and hauling the gear, mending the nets, repairing the gear where necessary, and gutting and stowing the fish. On the distant water trawlers the deckmen are divided into four watches and are on duty for 18 out of 24 hours. A quarter of the men are below for 6 hours' rest at all times. Additional rest may be had in slack fishing when the decks have been cleared of fish. On middle and near water trawlers there may be no allocated time below. Except when on watch, the men find rest between hauls when gutting fish is finished. Watches during fishing are timed to correspond with the hauling of the gear, usually every three hours. Operations are carried out at the utmost speed. The nets must be trawling for the maximum amount of time. Time lost in shooting or hauling or in repairs means less fish caught, a smaller total catch, and consequently a decrease in earnings. When the gear goes over the side, the fish on deck must be gutted, washed, and cleared below to the fish rooms before the next haul is due. This will be in two to three hours, depending on whether fish are plentiful or not. Should the gear become fastened on the sea bottom, it will have to be hauled prematurely.

The trawler is a very unstable vessel and this work is carried out on a pitching and rolling deck in all weathers, rain, hail, snow or ice. On most ships, fishing continues even in gale force winds. Gutting will continue till finished, whatever the force of a gale.

In the fish rooms, ice becomes impacted into a solid mass on the outward journey and must be chopped free and broken into small pieces and shovelled to the section of the fish room where fish are being stowed. In slippery and cold conditions, they are sorted into species and stowed between layers of ice.

Work eases up again on the homeward journey. The gear is stowed away and the deck is cleared, scrubbed, and hosed down. The whole crew joins in the cleaning of the ship. Togs are changed, hair is oiled, and many days' growth of stubble is shaved off. The trawler and crew are then shipshape for the return to port.

Engineers and firemen Engineers and firemen relieve each other on alternate six-hourly watches. Their work in the engine rooms is under hot, humid and noisy conditions. The noise in the modern diesel trawler is particularly intense. Space is very confined in the older and converted steam trawler, but in the more modern trawler the working area is greater. 
Cook The cook provides breakfast from 7 to 8.0 a.m., dinner from 12 noon to 1.0 p.m., and tea from 6 to 7.0 p.m. The first half hour is taken by those going on watch and the second by those coming off. Supper is cold and is left out by the cook before going off duty.

The galley is usually small, approximately $8 \times 13 \times 8 \mathrm{ft}$. on the smaller trawlers, although somewhat larger on the modern ones. It is always very hot. Most trawlers nowadays have a large refrigerator. Consequently, the cook has a wide range of foodstuffs and is not restricted to tinned foods as in the past. Bread brought on board is eaten within the first few days, and the cook must therefore be able to bake.

\section{Crew accommodation}

The crew accommodation on the post-war trawler is of a reasonable standard but, because of the size of the trawler, the accommodation is confined and crew members live in close proximity throughout the voyage.

The provision and arrangement of sleeping accommodation varies with the design and size of the ships. It is very cramped on the smaller near water trawler, especially if forward in the forecastle as on the older type of vessel, whereas on the modern distant water trawler separate cabins with greater floor space can be provided and all accommodation is amidships or aft, thus avoiding the necessity of crossing the deck in all weathers to reach the forecastle. On the older ships only the skipper has separate accommodation. On the newer vessels the mate, third hand, engineers, cook, and radio operator also have their own individual cabins. Where accommodation is not separate, it is usually divided into compartments so that the crew who are below and asleep are not disturbed by others.

The post-war vessel has separate mess rooms for officers and crew and a galley with adequate storage and refrigeration space. There is central heating and air conditioning. Hot and cold water are available and there are wash-hand basins, baths and/or showers, and separate water closets. Where natural lighting is poor or absent there is adequate artificial light. Reading lamps are provided for each bunk.

On the modern diesel trawler, which has dispensed with trawling from the port side, use has been made of the extra available space to provide improved accommodation which can be reached under cover.

On the stern trawler new facilities include a laundry room with a domestic washing machine and a recreation room where films can be shown, and a few have a sick berth. However, this type of vessel still forms a very small part of the fleet.

In 1966, the International Labour Conference at its 50th Session adopted a Convention concerning Accommodation On Board Fishing Vessels (Accom- modation of Crews (Fishermen) Convention, 1966). This represents the culmination of the preparatory work carried out in 1962 and 1965 by the International Labour Organisation which was recorded in two reports (International Labour Organisation, 1962 and 1965). The United Kingdom is one of the countries which has already ratified the Convention. The Crew Accommodation Requirements (Part III) are defined in 11 articles covering 86 items and set a high standard. For example, there are articles on heating and lighting and sleeping, messing, and sanitary accommodation. Also included are items on insulation and ventilation.

In the annex of the second report on Accommodation on Board Fishing Vessels (International Labour Organisation, 1965), proposals for the form of the new Convention were laid down. To see how a modern fleet fulfilled the requirements of the proposed Convention, towards the end of December 1966 , not having yet received a copy of the Convention but using the requirements of the proposed Convention as set down in the annex, the writer, who had taken up an appointment in Hull, arranged for an informal survey of trawlers sailing from that port. (The proposed and adopted Convention differ only in a few minor changes and certain typographical refinements.) This survey showed that Hull trawlers came close to the standard laid down in the proposed Convention (Appendix I).

At December 31, 1965, of 146 Grimsby trawlers, $141(96.6 \%)$ had been built since the war. Only five of the older distant water trawlers remained, two of which were built between 1931 and 1940, and three between 1941 and 1945 (White Fish Authority, 1966).

\section{Remuneration}

The crew, except the skipper and mate, are paid a basic weekly wage and receive a share in the proceeds of the sale of the catch which is known as poundage. The radio operator directly employed by the trawler owners is paid according to his length of service in trawlers.

The livers of gutted fish are processed aboard the trawler and the proceeds from the sale of fish liver oil are divided equally between the owners and the crew. The crew's portion is shared equally between the crew members, except for the deck learner and the galley boy, who each receive a half share.

Each fisherman is entitled to 26 days' holiday with pay. He often accepts the money (his 'holiday pay') but does not take the holiday for fear that he may lose his place on a favourite ship.

Food is provided by the trawler owners for the ship's crew, but the skipper and mate have the cost deducted from their earnings. All crew members must provide their own clothing and bedding. 


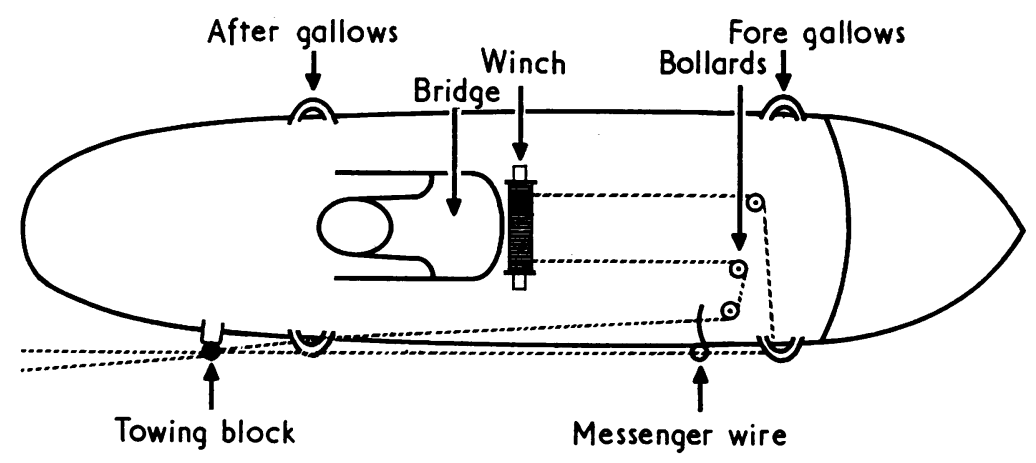

FIG. 3. A plan of the trawler showing the course of the warps from the winch to the towing block.

\section{The trawl and fishing operations}

The trawl is made up of a huge conical net and the apparatus which keeps it in position on the sea bed and connects it to the trawler during towing. Hauled over the sea bed, fish are trapped by the large open mouth and held in its narrower, elongated, terminal portion (the cod-end).

The trawler hauls the net through the water by means of warps which are steel ropes (Fig. 2). They are coiled on to the winch which is situated on the deck forward of the bridge (Fig. 3). They run forward from the winch, around bollards and then on to the fore and after gallows.

The gallows are the strong points on the side of the ship from which the trawl gear is towed. They are inverted ' $V$ ' shaped girders about $12 \mathrm{ft}$. high built into the ship. There are four on the conventional trawler, two on each side. Most trawling, probably all nowadays, is done from the fore and aft gallows on the starboard side.

From the gallows the warps run aft to be brought together at the towing block before passing to the trawl on the sea bed (Fig. 3). The towing block is fitted to the ship's rail near the stern of the trawler and holds the warps clear of the propeller and makes for easier manoeuvring of the ship and trawl.

The mouth of the net is maintained in the open position by a number of devices. The warps are attached to otter boards, also known as trawl doors or 'the doors' (Figs' 4 and 5). These are large structures made of wooden planking and steel, usually $10 \times 4 \mathrm{ft}$. and weighted at their base by a protective iron shoe (Fig. 5). The otter boards swim away from each other, spreading the net and opening its mouth to its full extent horizontally. They also hold it on the bottom.

${ }^{1}$ The photographic illustrations are some of those taken by the writer during a three-week voyage to the Icelandic fishing grounds in May 1964. Extracts from the diary of the voyage are given in Appendix II.
Hollow metal floats or bobbins (sometimes called 'cans') (Figs 5 and 6) are fixed to the upper part of the mouth of the net and draw it upwards. Heavy steel bobbins (some are wooden in the North Sea trawlers) from $\frac{3}{4}$ to $2 \frac{1}{4} \mathrm{cwt}$. in weight (Fig. 6) hold the lower part on the sea bed (Fig. 2). In this way the mouth of the net is held open vertically.

The sweep or opening of the net varies from 50 to $80 \mathrm{ft}$. across; its overall length is $160 \mathrm{ft}$. These dimensions apply to the usual size of trawl. Some are larger and some smaller by $20-30 \mathrm{ft}$. The trawl doors weigh 12-15 cwt. each. It is estimated that the combined weight of the trawl, trawl doors, and warps is about seven tons, some weighing more and some less by a few tons. The weight of a 'bag' of fish (Fig. 7), the maximum hove on board at any one time, is 200 st.

\section{Preparing the deck for fishing}

Before fishing begins, in addition to preparing the trawl, the deck is made ready. The washing machine is assembled. The deck is divided into sections or pounds, 6-8 $\mathrm{ft}$. square, by means of portable pound boards usually made of wood (Figs 8 and 9) and fitted between deck stanchions to receive fish from the cod-end (Fig. 8).

There are many hazards to trawlermen during fishing operations even in preparing the decks. Injuries are caused by trawlermen falling on or across the pound boards or against deck stanchions. When knocked down by seas coming aboard, trawlermen are washed about the deck and against the washing machine, fish room hatch covers, deck stanchions, the winch, and other obstructions on deck.

\section{Shooting the trawl}

The deckmen turn out and group themselves round the fore and aft gallows. Two of them man the winch. Using lifting gear connected to the winch, the trawl doors are hoisted, in turn, into position 
FIG. 4. Securing the after trawl door. Trawler has rolled to port and trawl door has swung against ship's side. Deck hand leans over to secure door to the gallows. on the gallows. Each is lifted clear of the ship's side and, with assistance from the roll of the ship, is manually pushed outboard before being chained to the gallows.

The trawler is turned broadside on to the wind, with the wind on the working side, usually the starboard so that, while shooting, the trawler is blown away from the trawl gear and net in the water.

The body of the net is then pushed over manually and, using the lifting gear, the remainder of the net is raised and dropped over the side. The bobbins, being still inboard, are hoisted overboard. To spread the gear the trawler swings towards it at half speed and again stops to lower the trawl doors. The gear is towed at full speed while the warps are paid out. The trawler then returns to its intended course, bringing the warps alongside. They are 'blocked up', i.e., secured in the towing block to prevent the warps fouling the propeller. The trawler gets under way at the correct towing speed and fishing begins.

The winch is in operation continuously during shooting and hauling and it is involved in many injuries to trawlermen. Fingers, hands, and arms are trapped between the warps and the winch. Trawlermen fall against it. The warps can catch a man's clothing or he can fall against them and be drawn into the winch or a bollard. Strands of wire project from the warps, causing injury to hands and fingers or catching the clothing. The warps are especially dangerous when they are being paid out with the trawler under way at full speed.

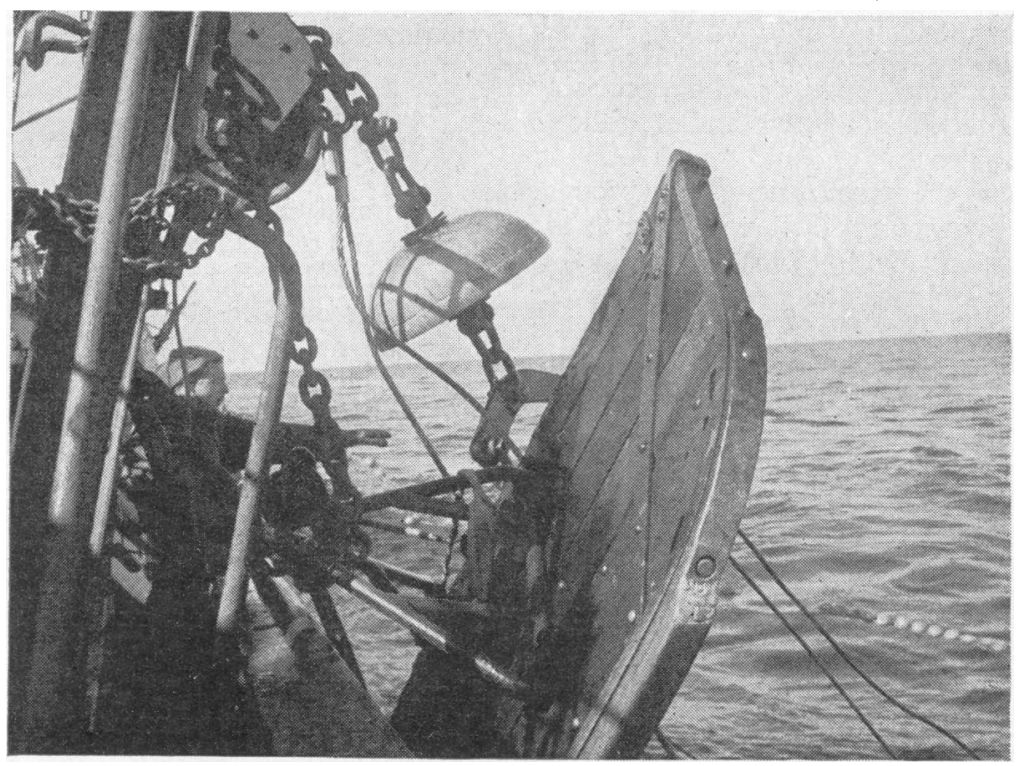

FIG. 5. The after trawl door and assembly hanging from aft gallows. Trawl door shows construction from wooden planking, iron shoe, and bracket. 


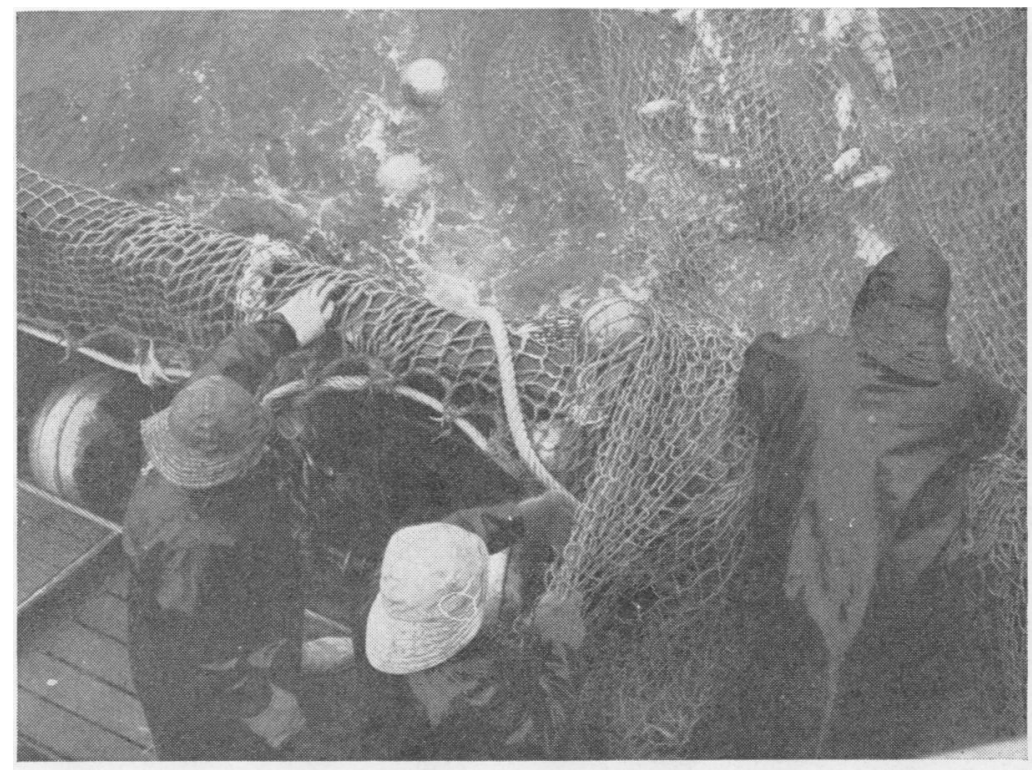

FIG. 6. Pulling in on the belly of the net. Steel bobbins have been hove on board and lie against the ship's wall. Smaller bobbins or 'cans' float in the sea. Bulwark of trawler is low in this area. Rolling of ship brings the seas aboard, and in rough weather waves break over trawlermen and may carry them overboard.

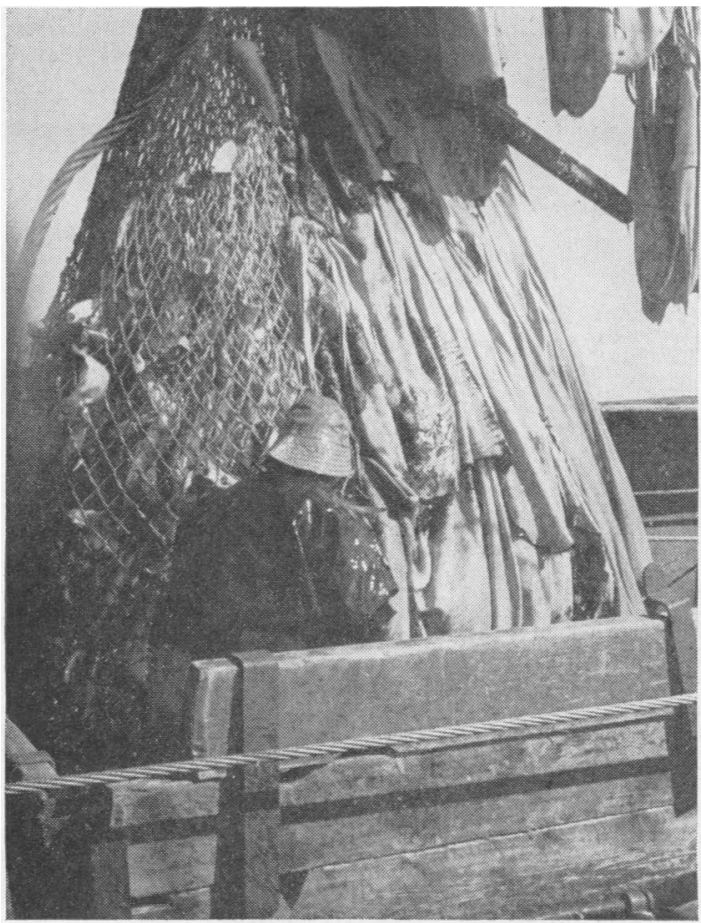

FIG. 7. The third hand lets go the cod-end. Third hand jerks free the codline, allowing a 'bag' of fish to cascade around him.
The lifting of the trawl door into position on the gallows from the deck, up and over the rail, has caused crush and trapping injuries to hands and arms, as it has to be pushed out over the rail (suspended by a steel rope) by a deck hand as the ship rolls away from him. The doors are also drawn up to the gallows with each haul and are released on shooting. In the pitching and rolling of the trawler, three-quarters of a ton of trawl door can swing wildly, and judgement and experience are required in manoeuvring it (Fig. 5).

Crushing and trapping of arms and hands on the ship's rail occurs when the heavy gear and bobbins are being put overboard and are later returned from the sea. They fall, injuring legs and feet.

'Blocking up' is dangerous. The warps having been pulled in to the ship's side, the deck hand has to fasten the towing block across them and secure them with a strong pin, at a time when they bear the full weight of the trawl with the trawler going ahead. The warp may jump free, due to stresses and strains and the motion of the ship, and cause serious injury.

\section{Hauling}

The engine room is warned so that the winch engine is started, and the deck men receive 10 minutes' notice to allow them to turn out properly dressed for the weather. 
FIG. 8. Fish of one catch just emptied out of the codends. Two bags of fish, or 100 baskets in this catch, fill four of the six fish pounds. Third hand works on codend. Gloves have been removed, exposing the hands and wrists to injury and infection. Bollard with warp at upper left corner. Entrails from gutting lie on deck.
To make the warps sheer away from the ship's side, the ship is steered to starboard. A length of forewarp is then winched inboard to level the trawl with the ship's side. The warps are then 'knocked out'. Using a seven-pound hammer, the third hand breaks the hinged towing block by knocking out the securing pin, and the warps spring away and the trawl with its catch of fish is brought on board.

The cod-end is lowered to about $3 \mathrm{ft}$. above the deck. The third hand goes under it, still flowing with water and fish slime, to unfasten partially the securing codline. Then, standing clear, he jerks the codline free and the fish cascade onto the deck around him (Fig. 7). The trawl is checked for damage and repaired if necessary. It is then ready to shoot once again.

The causes of injury due to manoeuvring the trawl are as described for shooting. Trawlermen attribute 'ruptures' of various kinds to the manual hauling of nets over the side (Fig. 6). It also causes muscular strains and joint sprains. 'Knocking out' is a more dangerous procedure than 'blocking up'. The towing block, 'broken' by the blow of a hammer, flies apart and aft and the warps spring away. The deck hand who is 'knocking out' should stand forward of the towing block. A deck hand in the wrong position may be severely injured.

Hauling and shooting continue day and night and in all kinds of weather. Waves break over the men hauling in the belly of the net. In winter the decks and apparatus may be covered by ice. The ship

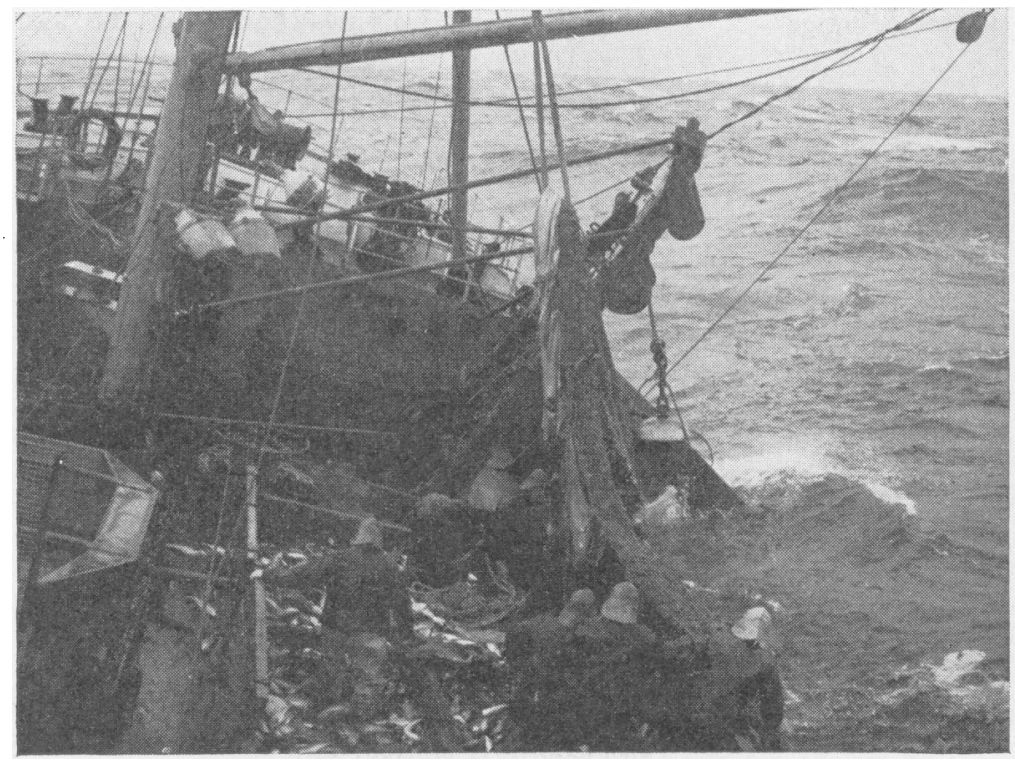

FIG. 9. The third hand ties the codline before shooting the trawl. Heavy roll to starboard with trawler shipping water over side as it lies broadside on to seas. 
pitches and rolls, swinging tons of gear to and fro.

The time between the trawl doors coming and going down again varies between 20 minutes and one hour, depending on the number of bags of fish and the need for repairs. All operations take place at great speed and team work is absolutely essential.

\section{Gutting}

Gutting and storing the fish takes place immediately the trawl has been shot. The gutting team stands in the pounds up to the knees in fish. The gutting knife is a finely sharpened clasp-knife. A fish is held in one hand, and its belly is cut open down the middle in a straight line as far as the vent by a swift movement of the other (Fig. 10). Another swift cut removes the liver, which is directed into a basket, and two more cuts remove the intestines. These movements are very rapid and the eye has difficulty in following them when performed by a skilled deck hand. The fish is then thrown into the washing machine.

Gutting is usually completed in one to one and a half hours but may continue until the next haul. While gutting, the deck hands are often covered in spray, and in winter waves break over them and may knock them down into the fish and cold water, or against or on top of the pound boards. Cold weather in the distant waters may cause the fish to freeze on deck. Whatever the conditions, the deck hand continues to gut until the last fish is below in the fish room.

Injuries to the hands are common, from knife cuts or from the pricks of fish bones and spines. The trawlerman is covered in blood, pieces of gut, and faeces (Fig. 10). He works for hours on end without hand washing and in dirty gloves, and wounds easily become infected.

\section{Medical aid available to Grimsby deep sea fishermen}

\section{Medical aid in the United Kingdom}

When ashore in the United Kingdom the deep sea fisherman, like the shore worker, receives medical care and treatment under the National Health Service and also qualifies for government social security benefits.

In addition, since 1961 the Grimsby trawlerman has been contributing to the Grimsby Trawler and Seine-net Crews' Personal Contributory Accident and Life Assurance Scheme (the Fisherman's Insurance Scheme), which insures him against accident or death occurring when signed on a vessel's articles. The Grimsby Exchange Clinic on the dock side is provided primarily for the treatment of the subscribing trawlerman, and he is required to have a medical examination by the Clinical Medical Officer as soon as possible after injury. The Medical 2

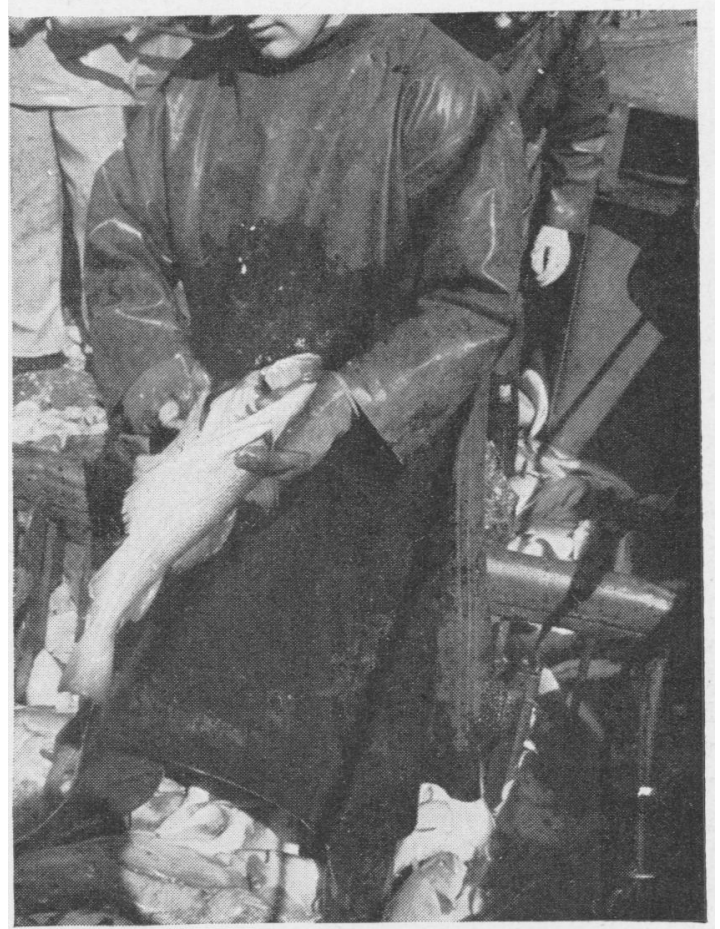

FIG. 10. Gutting a cod. Deck hand's smock covered in blood, fish slime, and faeces. Left sleeve of oilskin is rubbing wrist above glove.

Officer also gives a final clearance certificate before the fisherman re-signs on ship's articles.

\section{Medical aid at sea and overseas}

Once his ship puts to sea the trawlerman is immediately removed from the medical care so often taken for granted by the shore worker, such as the family doctor, the local hospital, the factory nurse or medical officer.

First aid At sea, the medical care of his crew becomes the responsibility of the skipper, but the first aid duties are usually allocated to the mate. Before gaining the Ministry of Transport Certificate of Competency, the skipper and mate have had to produce a certificate to the effect that they have passed an approved examination in first aid to the injured.

The medicine chest Under the Merchant Shipping Act, 1894, regulations require ships to carry medical stores and equipment and a copy of the current edition of The Ship Captain's Medical Guide (Board of Trade, 1967). The minimum amount of equipment to be carried by a fishing vessel is specified under The Merchant Shipping Medical Scales (Fishing Boats) Order, 1954, as amended by the Merchant 
Shipping Medical Scales (Fishing Boats) (Amendment) Order, 1961. There are two scales applying to fishing boats and scale I applies to trawlers. The drugs, instruments, and appliances have been chosen to allow first aid treatment in the most commonly occurring emergencies and for the nursing of the sick person. Drugs such as morphia and penicillin, which should normally be prescribed by a doctor, may be given by a skipper, provided he is acting on the advice given in The Ship Captain's Medical Guide.

'The Ship Captain's Medical Guide' The Guide (Board of Trade, 1967), as noted in its Preface, is 'primarily intended for use on ships not carrying a surgeon and the recommendations contained in it are confined necessarily to such measures of prevention and treatment as can be carried out by the layman'. It is a volume of 356 pages containing much more than the usual first aid manual. It is very doubtful whether the average skipper or mate has read this manual from cover to cover. Comments were made on the 'Northern Gift', on which the writer sailed to the Icelandic fishing grounds, about the difficulty of understanding what was in it despite previous training in first aid.

Recently, the International Medical Guide for Ships has been published (World Health Organisation, 1967) and is the first attempt at the international level to bring a ship's medical guide, medicine chest, and medical advice by radio together into one effective scheme.

Medical advice by radio Medical advice may be had from the shore or from another ship carrying a medical officer. Whilst in close proximity to the shores of the British Isles, the skipper can have direct communication with a doctor. At sea, the radio link is usually with another ship and a message may be relayed from ship to ship. A message requiring medical aid has priority over all others with the exception of distress signals. Skippers on the fishing grounds will contact a vessel of the Fishery Protection Squadron if one is known to be within distance of radio contact.

Rendezvous at sea Ships may arrange a rendezvous at sea so that a doctor may board a trawler, or a sick or injured trawlerman be taken off. Near the coasts of Great Britain, rendezvous is often with a lifeboat or helicopter, and on the fishing grounds with ships of the Fishery Protection Squadron (vide infra).

Medical aid ashore overseas Trawlers put into foreign ports, for example in Iceland and Norway, so that a doctor may be consulted.

In 1963, 165 Grimsby trawlermen were taken ashore for treatment, 103 as a result of injury and
TABLE 4

Ports at Which Grimsby TraWlermen WERE LANDED FOR TREATMENT OF INJURY AND ILLNESS IN 1963, SHOWING THE NUMBER LANDED AT EACH PORT

\begin{tabular}{|c|c|c|c|}
\hline Port & Injuries & Illnesses & Total \\
\hline $\begin{array}{l}\text { Greenland } \\
\text { Faeringehavn }\end{array}$ & 1 & - & 1 \\
\hline $\begin{array}{l}\text { Iceland } \\
\text { Isafjord } \\
\text { Thingeyri } \\
\text { Others }\end{array}$ & $\begin{array}{r}2 \\
19 \\
5 \\
22\end{array}$ & $\begin{array}{r}-12 \\
5 \\
6\end{array}$ & $\begin{array}{r}2 \\
31 \\
10 \\
28\end{array}$ \\
\hline Total & & & 71 \\
\hline $\begin{array}{l}\text { Norway } \\
\quad \text { Harstad } \\
\text { Honningsvag } \\
\text { Others }\end{array}$ & $\begin{array}{r}3 \\
4 \\
5 \\
14\end{array}$ & $\begin{array}{r}- \\
6 \\
5 \\
10\end{array}$ & $\begin{array}{r}3 \\
10 \\
10 \\
24\end{array}$ \\
\hline Total & & & 47 \\
\hline $\begin{array}{c}\text { Faeroes } \\
\text { Klaksvig } \\
\text { Others }\end{array}$ & $\begin{array}{l}6 \\
7\end{array}$ & $\begin{array}{l}5 \\
4\end{array}$ & $\begin{array}{l}. \\
11 \\
11\end{array}$ \\
\hline Total & & & 22 \\
\hline $\begin{array}{r}\text { Denmark } \\
\text { Esbjerg }\end{array}$ & 1 & - & 1 \\
\hline $\begin{array}{l}\text { United Kingdom } \\
\text { Scrabster } \\
\text { Others }\end{array}$ & $\begin{array}{r}4 \\
10\end{array}$ & $\begin{array}{l}5 \\
3\end{array}$ & $\begin{array}{r}9 \\
13\end{array}$ \\
\hline Total & & & 22 \\
\hline Not specified & 一 & 1 & 1 \\
\hline Total & 103 & 62 & 165 \\
\hline
\end{tabular}

62 because of illness. Table 4 shows the ports at which fishermen were landed.

\section{Medical aid to trawlermen by the Icelandic Patrol of the Fishery Protection Squadron}

In the examination of the $\log$ books of Grimsby trawlers, it was noted that 27 Grimsby fishermen received medical aid from vessels of the Fishery Protection Squadron in 1963. The Medical DirectorGeneral (Naval) of the Ministry of Defence was approached for particulars of assistance given to trawlers. Although precise records were not available of all such treatment given, extracts were forwarded from the relevant reports received from H.M. Ships on the Icelandic Patrol for the period January 1 to September 30, 1963. No records were available for the last quarter of the year.

Icelandic patrol vessels are usually frigates of the 
Royal Navy, carrying a medical officer and a leading sick bay attendant. The following information is extracted from the reports and includes details of medical assistance to all trawlers, not only those sailing from Grimsby.

The medical officer's journal

In the period January 1 to September 30, 1963, 10 quarterly reports were received from five ships of the Squadron. All reports except one from the leading sick bay attendant were from the medical officer.

It is usual for H.M. Ships to sail along the 12-mile limit line which does not always coincide with the fishing grounds. The length of time on the grounds will depend on the other duties of the patrol. The journal does not specify the actual time spent on the grounds. The period between the first and last cases treated (Table 5) gives some indication but a vessel may put into a port or steam between fishing grounds during this time. Consequently, the duration of the periods in contact with trawlers is very irregular.

The period covered by the reports from different ships is shown in Table 5, as is also the total number of cases treated and the number from Grimsby, and the dates on which the first and last cases were recorded for each report.

Methods of medical assistance to trawlers In all cases the first contact between the trawler and the Squadron ship was by radio-telephone. The different methods of assistance are shown in Table 6. In eight cases medical assistance was given when there was no medical officer on board, and treatment was probably advised by the leading sick bay attendant.
TABLE 6

Method of Medical Assistance to Grimsby and All Trawlers by Ships of the ICELANDIC Patrol of the Fishery Protection SQuadron

\begin{tabular}{|c|c|c|}
\hline Method of assistance & $\begin{array}{l}\text { Grimsby } \\
\text { trawlers }\end{array}$ & $\begin{array}{c}\text { All } \\
\text { trawlers }\end{array}$ \\
\hline 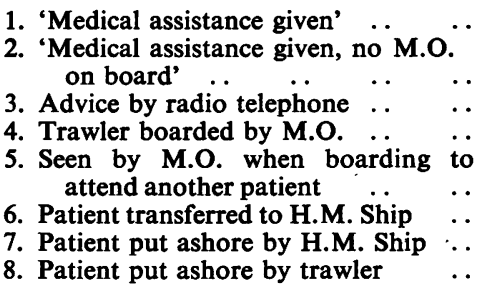 & $\begin{array}{l}- \\
1 \\
13 \\
21 \\
2 \\
4(2) \\
5(\underset{1}{(1)})\end{array}$ & $\begin{array}{r}6 \\
8 \\
30 \\
30 \\
3 \\
12(5) \\
8(5) \\
23^{1}(2)\end{array}$ \\
\hline Total & 56 & 120 \\
\hline $\begin{array}{c}\text { Total no. of times the trawler was } \\
\text { boarded by M.O. }\end{array}$ & 24 & 42 \\
\hline
\end{tabular}

The figures in parentheses show the number of times the M.O. boarded the trawler, in addition to those shown in line 4.

${ }^{1}$ Includes three deaths.

In over one-third of the instances the medical officer boarded a trawler to see a patient. When one considers that the Fishery Protection Vessel can be anywhere on the fishing grounds, often only within radio distance of a trawler seeking aid, it seems that the medical officer boarded on all occasions possible.

Injuries and illnesses The medical officer's journal gives very brief details of individual incidents. The

TABLE 5

Periods covered by the Medical Officers' Journals from H.M. Ships of the Fishery Protection SQuAdron IN 1963, SHOWING the Number of GrimsBy aNd the Total Number of Fishermen treated and the Dates of the First and Last Treatments in Each Period

\begin{tabular}{|c|c|c|c|c|c|c|c|}
\hline \multirow{2}{*}{\multicolumn{3}{|c|}{ H.M. Ship }} & \multirow{2}{*}{$\begin{array}{c}\text { Period covered by } \\
\text { report }\end{array}$} & \multicolumn{2}{|c|}{ Date treated } & \multicolumn{2}{|c|}{ No. of cases treated } \\
\hline & & & & First case & Last case & Grimsby & Total \\
\hline $\begin{array}{l}\text { Malcolm } \\
\text { Palliser .. } \\
\text { Russel .. } \\
\text { Russel .. } \\
\text { Malcolm } \\
\text { Palliser }{ }^{1} . . \\
\text { Keppel . } \\
\text { Malcolm } \\
\text { Palliser .. } \\
\text { Duncan .. }\end{array}$ & $\begin{array}{l}. \\
\ldots \\
\cdots \\
\cdots \\
\cdots \\
\cdots \\
\cdots \\
\cdots \\
\cdots\end{array}$ & $\begin{array}{l}. \\
\ldots \\
. \\
\ldots \\
\ldots \\
\ldots \\
\ldots \\
\ldots \\
\ldots\end{array}$ & $\begin{array}{r}1.1 .63-31.3 .63 \\
1.1 .63-31.3 .63 \\
2.1 .63-21.2 .63 \\
9.3 .63-7.4 .63 \\
1.4 .63-30.6 .63 \\
1.4 .63-30.6 .63 \\
22.4 .63-30.6 .63 \\
1.7 .63-30.9 .63 \\
1.7 .63-30.9 .63 \\
1.7 .63-30.9 .63\end{array}$ & $\begin{array}{l}13.3 .63 \\
27.1 .63 \\
\text { Not given } \\
27.3 .63 \\
7.5 .63 \\
16.4 .63 \\
27.5 .63 \\
1.7 .63 \\
10.8 .63 \\
29.7 .63\end{array}$ & $\begin{array}{l}25.3 .63 \\
22.2 .63 \\
\text { Not given } \\
3.4 .63 \\
27.6 .63 \\
29.4 .63 \\
11.6 .63 \\
26.9 .63 \\
26.8 .63 \\
6.8 .63\end{array}$ & $\begin{array}{r}8 \\
1 \\
2 \\
5 \\
3 \\
12 \\
14 \\
8 \\
3\end{array}$ & $\begin{array}{r}13 \\
7 \\
2 \\
8 \\
8 \\
11 \\
11 \\
16 \\
29 \\
12 \\
11\end{array}$ \\
\hline \multicolumn{6}{|c|}{ Total } & 56 & 120 \\
\hline
\end{tabular}

${ }^{1}$ No medical officer on board. 
date of the incident, the name of the trawler, the method of contact between the trawler and H.M. Ship are given, together with a few notes on the condition of the fisherman and his treatment. There are usually no details of occupation or age or how an injury occurred.

The following is an example of recorded incidents picked at random from a medical journal from April 22 to June 30, 1963.

"6.6.63. "Northern Reward" advised by radio in a case of presumed cervical adenitis. Later visited and patient transferred to H.M.S. Keppel with the diagnosis of glandular fever. "Vizalma" advised by radio in treatment of septic finger. "Coventry City" visited concerning a patient with injury to ribs. No evidence of bony injury. Advised. 8.6.63. "Port Vale" advised by radio on treatment of lacerated finger.'

The following are examples of injury and illness and their treatment. Additional information has been acquired from other sources, e.g., the trawler log books and hospital records.

1. An injury took place on board a Belgian trawler. A French deck hand had his right little finger crushed in the trawl gear. He was transferred to H.M. Ship by life raft, and on examination was found to have a partial amputation of the finger with a compound fracture-dislocation of the proximal interphalangeal joint. The medical officer treated by surgical amputation and the deck hand was later landed at Nordfjord.

2 and 3. Two injuries occurred on a trawler in a force 9 blizzard. One was a fractured wrist and advice was given by radio telephone regarding splinting and the application of a sling; 1 gr. morphia was ordered. The other injury was to a fisherman who was knocked down by a sea and washed along the deck. He had bruising around the eyes and bleeding from the ears and showed no signs of life. The medical officer diagnosed a fracture of the base of the skull with intracranial haemorrhage and he advised the skipper to put in to Isafjord.

4. A radio-telephonic link-up was made from the trawler 'St. Elston' via the trawlers 'Northern Prince' and 'Coldstreamer' of Grimsby to H.M. Ship. A fisherman aged 63 was complaining of chest pain and breathing heavily. He had a rapid and irregular pulse. He had been taking heart tablets for three years since an attack of breathlessness with blackouts. The medical officer advised that he be propped up and, if his pain and restlessness became worse, that he be given morphia. The trawler was to make for the nearest port (Seydisfjord) as soon as possible.

5. A fisherman attempted to take his life. The medical officer boarded to find him acutely disturbed and transferred him to H.M. Ship. He was kept under sedation and two days later, after consultation with the Medical Officer of Health, Akureyri, was landed. He was escorted by the leading sick berth attendant for air passage home via Reykjavik.

The logging of injuries and illnesses The Fishery Protection Squadron rendered medical aid to 120 fishermen. Although there is a statutory requirement to do so (Merchant Shipping Act 1894), of 56 cases of medical aid to Grimsby fishermen, only $27(48 \%)$ were logged (Table 7). There were 28 injuries and 28 illnesses. Nineteen $(68 \%)$ of the injuries were logged but only eight $(29 \%)$ of the illnesses.

TABLE 7

NUMBER OF FisHeRMEN TREATEd By FisheRY Protection SQuadron IN 1963, SHOWING NUMBER OF INCIDENTS LOGGED AND INJURIES AND ILLNESSES OF GRIMSBY TRAWLERMEN

\begin{tabular}{|c|c|c|c|}
\hline Port & Injuries & Illnesses & Total \\
\hline $\begin{array}{l}\text { Grimsby } \\
\text { Logged } \\
\text { Not logged } \\
\text { Total }\end{array}$ & $\begin{array}{rr}19 & \\
9 & \\
& 28\end{array}$ & $\begin{array}{rr}8 & \\
20 & \\
& 28\end{array}$ & $\begin{array}{ll}27 & \\
29 & \\
& 56\end{array}$ \\
\hline Non Grimsby & & & 64 \\
\hline Total & & & 120 \\
\hline
\end{tabular}

Table 8 shows the types of injury and whether or not they were logged. All except the amputation and the infected lesion were treated by the medical officer on board the trawler, i.e., they are likely to have been of a severe nature. He advised by radio telephone regarding the amputation, which appeared

TABLE 8

INJURIES IN GRIMSBY FISHERMEN TREATED BY THE Fishery Protection SQUadron, SHOWING THOSE LOGGED AND NOT LOGGED

\begin{tabular}{l|c|c|c}
\hline \multicolumn{1}{c|}{ Lesion } & Logged & $\begin{array}{c}\text { Not } \\
\text { logged }\end{array}$ & Total \\
\hline Contusion & 4 & 6 & 10 \\
Laceration & 4 & - & 4 \\
Amputation & - & 1 & 1 \\
Fracture & $5^{1}$ & - & 5 \\
Sprain/strain & 3 & - & 1 \\
Eye injury & 1 & - & 1 \\
Burn & - & 1 & 3 \\
Infected trauma & 2 & 9 & 28 \\
\hline Total & 19 & & \\
\hline
\end{tabular}

${ }^{1}$ Includes one dislocation. 
TABLE 9

ILlNesses in Grimsby Fishermen tReated by the Fishery Protection SQuAdron, SHOWing THOSE LOGGED AND NOT LOGGED

\begin{tabular}{|c|c|c|c|c|c|c|c|c|c|}
\hline \multicolumn{7}{|c|}{ Illness } & Logged & Not logged & No. \\
\hline Aural $\quad$. & .. & . & . & . & . & . & Otitis externa & & 1 \\
\hline Pharyngeal & .. & .. & . & . & .. & . & & Tonsillitis & 1 \\
\hline Respiratory & . & .. & . & . & . & . & Influenza & $\begin{array}{l}\text { Influenza }(5) \\
\text { Upper respiratory tract infection } \\
\text { Chronic bronchitis }\end{array}$ & 8 \\
\hline Cardiac... & . & .. & . & . & .. & . & Coronary thrombosis ${ }^{1}$ & & 1 \\
\hline Oral & . & . & . & . & . & . & & Dental abscess & 1 \\
\hline Gastrointestina & & .. & .. & . & .. & . & $\begin{array}{l}\text { Haematemesis } \\
\text { Appendicitis } \\
\text { Hernia (2) }\end{array}$ & $\begin{array}{l}\text { Abdominal pain } \\
\text { Gastric ulcer } \\
\text { Intestinal obstruction } \\
\text { Hernia } \\
\text { Umbilical discharge }\end{array}$ & 9 \\
\hline Venereal & . & . & . & . & . & . & & Non-specific urethritis & 1 \\
\hline Infectious & . & . & . & . & . & . & Glandular fever & & 1 \\
\hline Neurological & . & . & . & . & .. & . & & Neuralgia & 1 \\
\hline Dermatological & & .. & .. & . & .. & . & & $\begin{array}{l}\text { Boils (2) } \\
\text { Scabies } \\
\text { Infected sebaceous cyst }\end{array}$ & 4 \\
\hline Total & .. & .. & .. & $\cdots$ & .. & $\ldots$ & 8 & 20 & 28 \\
\hline
\end{tabular}

1 One death.

to 'be clean and healing', and the infected lesion.

Illnesses logged and not logged in their different categories are shown in Table 9. Of the 20 cases logged, 12 were seen by the medical officer when he boarded the trawler. In the others, advice was given by radio-telephone. They included a dental abscess, which caused a temperature of $100^{\circ} \mathrm{F}$. and difficulty in opening the mouth; tonsillitis with a temperature of $103^{\circ} \mathrm{F}$. and enlarged cervical glands; influenza of two days' duration with a temperature of $100.4^{\circ} \mathrm{F}$.; a left inguinal hernia; and intestinal obstruction. Again, these at least seem to be of sufficient severity to warrant logging.

\section{Discussion}

Comparatively little is known of the health of deep sea fishermen and there is little on the subject in the medical literature. As almost one quarter of the deep sea trawlers of the United Kingdom sail from Grimsby, more than from any other port (Table 2), and they fish at near, middle, and distant water fishing grounds, a study of Grimsby deep sea fishermen should give a fair picture of the conditions in the industry as a whole.

For a fishing vessel, the trawler is much larger than is usually imagined. Its size, flaring bows, sleek lines, and powerful appearance demonstrate that it is a sea-going vessel, remaining on the high seas for longer - often several weeks longer - than a merchant vessel on the average trans-Atlantic voyage. It is built not only to carry a cargo of fish but also to take its cargo on board at sea. The amount of space available for the crew is therefore reduced to the minimum and will vary according to the size of the vessel. Even on the larger trawler it is cramped and confined by comparison with most merchant vessels, and trawlermen live and work in close proximity and usually share crew quarters.

There has been an improvement in crew accommodation in recent years which will continue as the older ships are replaced. The informal survey of the Hull fleet (Appendix I) showed that it came close to the standard required by the Accommodation of Crews (Fishermen) Convention 1966 of the International Labour Organisation. However, it was found that in this sample of a modern fleet, in almost three-quarters $(72.6 \%)$ of the trawlers, men sleep more than four to a cabin and on more than a quarter $(28.3 \%)$ there is accommodation in the forecastle. In a survey of 100 Grimsby fishing vessels carried out in 1947, Syme (1949) found that in $10 \%$ no sanitary convenience was provided, while in $21 \%$ of the remaining vessels the conveniences provided were not being used, chiefly because of the exposed position and uninviting nature of the structures. That all Grimsby trawlers now sailing have adequate sanitary accommodation illustrates one aspect of the improvement of crews' accommodation in recent years. 
The deep sea fisherman, in addition to living in confined quarters, has to put up with conditions throughout the voyage which, at best, are those of physical discomfort. Noise and vibration reach all parts of the ship and are continuous. The trawler, too, is in continuous motion, pitching, rolling, and yawing. Even in fair weather a sudden lurch can throw a trawlerman in any direction. Conditions worsen in heavy weather. Although trawler berths have high sides (lee boards), making it difficult to climb in and out, sleeping trawlermen have been thrown right out of their berths. Conditions of continuous noise and vibration must surely add to the fatigue experienced by the trawlerman in his work, and the instability of trawlers account for many of the injuries, due to falling, slamming doors, and swinging trawl apparatus.

While fishing, the trawlerman's work is continuous. He works in a team and must do his stint. Any slackening is noted and may be the cause of his replacement at the end of a voyage. The trawlerman who is alert and keen to danger when fishing begins will, because of fatigue, become increasingly liable to accidental injury as fishing continues. Hours of work are long (especially for boys of 16, 17, and 18). They can only be shortened by employing more trawlermen on each vessel. Although trawlers have increased in size, the number in the crew has not increased since 1946. The Polish distant water trawler, equivalent in size to the British trawler carrying a crew of 20 , is manned by 28 trawlermen (IVth International Trade Conference, 1965).

The shore worker returns home after a day's work. The fisherman remains on the job even when off duty. There is no recreation and few books on board other than what he brings with him. As the voyage lengthens he becomes increasingly bored. There is no cinema, 'local', family or friends to break up the monotony. No mail arrives. When he tires of the company of his ship-mates, there is nowhere to retire. Boredom added to fatigue increases still further the risk of accidental injury.

The method of payment, according to the amount of fish caught, has many implications. Since the crew works as a team, a member falling out of that team affects the earnings of the rest. Therefore the trawlerman continues working, even when suffering from injury or illness. On occasion this can cause a deterioration in his condition. Because of the method of payment the trawlerman may take unnecessary risks on deck. The skipper must keep down the overall cost of the trip as the skipper who has high running costs and a low catching record is soon replaced. Will he be tempted therefore not to put the injured or sick fisherman ashore as early as he should? Will he take that extra risk which will put his ship and his crew in danger? Will he leave the trawl on the sea bottom a little longer even when the weather is worsening, thus making the hauling more difficult and dangerous? A change in the method of payment could eliminate to some extent these factors which have an important bearing on the health of the deep sea fisherman. At the present time the poundage earned, for example by a third hand, varies from $52.5 \%$ (on a near water trawler) to $68 \%$ (on a distant water trawler) of his total earnings. Trawlermen are unlikely to give up the share system as a method of payment, but an increase in the basic wage and less for poundage might remove some of the pressure on trawlermen to catch fish at any cost to life and limb.

The medical aid to and the treatment of trawlermen is not at all satisfactory. While ashore he has the family doctor and the facilities of the National Health Service and, depending on the port from which he sails, he may benefit from some form of occupational health service, usually run in conjunction with a local accident insurance scheme. However, this aid is available only when he is ashore for a few days after 10-21 days at sea or longer. Many trawlermen have not registered with a general practitioner nor do they belong to an insurance scheme, even if it is available. Of 38 trawlermen investigated, whose general pactitioners were being sought to provide additional information, 18 were not registered with a general practitioner. Only when injury or illness overtakes them do trawlermen seek medical advice and 'turn up' at a clinic. There is no occupational health service for trawlermen which has an oversight of all men in the industry.

When at sea, medical care becomes the responsibility of the skipper. The skipper's knowledge (and that of the mate) is limited to a course of first aid which was taken so that he could qualify for the Certificate of Competency, at a time when he was not really interested in the subject, and it may have been taken many years ago. He may consult The Ship Captain's Medical Guide, using the contents of the medical chest for treatment, get advice from shore or a ship carrying a medical officer, or make for the nearest port to seek medical aid or to land his indisposed trawlerhand. The order of preference, as revealed by this investigation, seems to be that the skipper will in the first instance contact a medical officer of a Fishery Protection Vessel if one is within reach of radio contact, put in to the nearest port or lastly consult the Guide. Fishery Protection Vessels do very irregular patrolling of the grounds and do not always carry a medical officer. The skipper may therefore have to decide whether or not to give up fishing and put in to port. In making his decision, he must balance his losses from the cessation of fishing against the severity of the injury or illness and the need to put the trawlerman ashore. Because of a lack of adequate training in first aid and unfamiliarity with The Ship Captain's 
Medical Guide, he may be unable to judge the latter, so that the trawlerman may suffer by getting inadequate or delayed treatment. This is aggravated by the fact that the trawlerman will not go sick and his condition may already have worsened before it is brought to the notice of the skipper and the necessary action is taken. During 1963, after seven days' illness at sea, a cook was found to have pneumonia on being put ashore; a galley boy, ill at sea for 16 days with 'gastro-enteritis', received six morphia injections before being put ashore; a radio-operator landed after 12 days of illness at sea had a perforated appendix; and a mate died from appendicitis and peritonitis after three days of illness at sea. Because of inadequate or delayed treatment, conditions are seen in trawlermen which are rarely seen ashore, e.g., quinsy, dental abscesses with trismus, and severe palmar space infections.

With proper training of skippers or mates, lacerations could be sutured and abscesses incised but only six of the former and four of the latter were so treated (this journal, p. 25). Also if instruction were given in the use of penicillin, many infections could be controlled or cured. Although infected trauma formed the second largest group of injuries, only five trawlermen were treated by their skippers with penicillin tablets. Only nine trawlermen received morphia, usually on the instructions of a doctor.

It is essential, therefore, that skippers and mates should have a thorough training in first aid by persons who know the conditions on board trawlers and are familiar with The Ship Captain's Medical Guide. The standard required should be higher than that acceptable from the amateur first-aider. The Ship Captain's Medical Guide should be introduced to the trawlerman at this stage and not when he is confronted for the first time with disability at sea. There should be refresher courses at regular intervals with no financial loss to those who take the course, and it would be advisable to extend the training to other trawlermen and not confine it to the skipper and his mate.

Skippers do not record all the incidents of injury or illness that occur on board trawlers. This is especially true in respect of illness. They vary in what they consider to be a serious incident and 'minor' ones are not recorded. The trawlerman continues at work with maladies which would cause his counterpart ashore to go off duty. What the trawlerman considers trivial is unlikely to be recorded in the log. Entries, on occasion, are made in the log book on return to port or in the last few days of the voyage, so that some incidents may have been forgotten and only the serious ones recorded. An experienced skipper advised the writer that the logging of injury probably gave a true record but that this was not so in respect of illness; if treatment was received from ships of the Fishery Protection
Squadron, and the trawlerman remained on his ship, the incident would not be recorded; and if a skipper brought his vessel home, although himself suffering from injury or illness, the incident also would not be logged.

Trawlermen were put ashore on 103 occasions for the treatment of injury and 62 times for illness (Table 4), i.e., throughout the year a trawler put in to port approximately every two days; or one in six trawlermen with logged injury and half those with logged illness were put ashore for treatment.

The work of the Fishery Protection Squadron was greatly appreciated by skippers, and the medical aid given by its medical officers was invaluable. From the information available it could be surmised that, with full-time patrolling of the fishing grounds, at least 15-20 fishermen per month would be likely to receive medical aid.

Hospital ships are provided on the fishing grounds by Holland and West Germany (Leiper, 1966), and it is often suggested that Great Britain should do likewise. Hospital ships are costly to maintain. As ships of many nations are found on the fishing grounds, international co-operation and the sharing of expense could provide a hospital ship or ships for all trawlermen. With proper first aid training of skippers as suggested, a hospital ship provided unilaterally by the United Kingdom would not be necessary since fishing grounds, although often distant from the British Isles, are usually relatively close to land, and the skipper, if unable to cope, may make radio contact with shore or put in to port. It is suggested that the medical services at ports overseas likely to be used by skippers should be surveyed and skippers advised of recommended ports where medical aid may be had if required. More regular patrolling by vessels of the Fishery Protection Squadron would be welcomed, because there is no language barrier in making contact, the assistance of fellow countrymen is more acceptable, and the presence of such a ship even in the remote area gives reassurance to the skipper already weighed down by many responsibilities, without genuine worry about a shipmate who may be no more than 'off colour' from a minor complaint. Should there be a serious malady, he would know that expert help was at hand.

The writer wishes to acknowledge the ready co-operation he has had from the Grimsby trawler owners and deep sea fishermen in this research, and in particular to note the valuable assistance of Mr. T. Cooper, Secretary of the Trawler Owners' Association at the Grimsby Exchange Ltd., and the late Skipper John Hobbs, Secretary of the Trawler Officers' Guild.

\section{References}

Accommodation of Crews (Fishermen) Convention 1966. Convention No. 126 concerning Accommodation on Board Fishing Vessels. International Labour Office, Geneva. 
Board of Trade (1967). The Ship Captain's Medical Guide, 7th ed. H.M.S.O., London.

Bowdler, A. J. (1954). Medicine in the Fishery Protection Service. J. roy. nav. med. Serv., 40, 184-186.

Burns, J. (1955). Deep sea trawling and some of its medical problems. Trans. Ass. industr. Med. Offrs, 5, 55-60.

Cooper, T. (1965). The world's premier fishing and frozen foods port. In the County Borough of Grimsby Official Guide, 4th ed., pp. 109129. Batiste Publications, London.

Ejsmont, W. (1958). The cases of illnesses of deep sea fishermen on fishing waters in 1955. Bull. Inst. mar. Med. Gdańsk., 9, 181-186. , and Szczeblewski, B. (1959). Evaluation of the nutrition of deep sea fishermen on base vessels (in Russian). Ibid., 10, 101-113.

Food and Agricultural Organisation of the United Nations. (1966). Year Book of Fishery Statistics, 20. Catches and Landings 1965. Map I. p. xxi; and Tables A1-8, p. a48-61.

Friemann, W., Overhoff, W., and Wolter, J. R. (1959). Augenerkrankungen in der Industriefischerei (Eye diseases in the fishing industry). Arch Gewerbepath Gewerbehyg., 17, 1-56. Abstract in Bull. Hyg. (Lond.), 1959, 34, 773-4.

Gillett, E. (1965). The history of Grimsby. In the County Borough of Grimsby Official Guide, 4th ed., pp. 49-64. Batiste Publications, London.

Goethe, H., Rinck, G., and Gudmundsson, G. (1959). Erkrankungen in der deutschen Hochseefischerei mit Berücksichtigung des Gebisszustandes. (Sickness in German deep sea fishermen with reference to dentition.) Arch. Gewerbepath Gewerbehyg., 17, 57-66. Abstract in Bull. Hyg. (Lond.), 1959, 34, 773.

Grant, G. L. (1961). An essay on fishermen, their health and their society. Dissertation for the Diploma in Public Health. University of Aberdeen.

Heijermans, L. (1930). Fishermen: sea fishing. Occupation \& Health, 1, 767-775.

International Labour Organisation. (1962). Accommodation on Board Fishing Vessels. International Labour Office. Geneva.

(1965). Accommodation on Board Fishing Vessels. International Labour Office, Geneva.

IVth International Trade Conference of Transport, Port and Fishery Workers (1965). Report on Current Problems of the Deep Sea Fishery Workers.

Leiper, J. (1966). Medical services in fishing fleets. In Medical Services in Transport, ed. Grant, J. S., Heggie, R. M., and Norman, L. G., pp. 125-136. Butterworths, London.

MacQueen, I. A. G. (1954). Some aspects of the health of trawl fishermen. An unpublished paper read at the Annual Conference of the Association of Sea and Air Port Health Authorities of the British Isles. Personal communication.

The Merchant Shipping Act 1894. H.M.S.O., London. P.G.A. 57 \& $58 \mathrm{Vic}, \mathrm{Ch} 60$.

The Merchant Shipping Medical Scales (Fishing Boats) Order, 1954. H.M.S.O., London. S.I. 1954 No. 1595.

The Merchant Shipping Medical Scales (Fishing Boats) (Amendment) Order, 1961. H.M.S.O., London. S.I. 1961 No. 1046.

Millar, C. W. (1959). The Icelandic Fishery Protection Patrol. J. roy. nav. med. Serv., 45, 159-161.

Ministry of Agriculture, Fisheries and Food (1967a). Sea Fisheries Statistical Tables 1965. H.M.S.O., London.

- (1967b). Number of deep sea fishermen regularly and occasionally employed in England and Wales in 1936 and 1961-66. Personal communication.

Ministry of Agriculture Fleck Committee Report (1961). Report of the Committee of Inquiry into the Fishing Industry. Cmnd. 1266. H.M.S.O., London.

Newhouse, M. L. (1966). Dogger Bank itch: survey of trawlermen. Brit. med. J., 1, 1142-1145.

Registrar General (1958). Decennial Supplement for England and Wales 1951. Pt. II, 1. H.M.S.O., London.

Schilling, R. S. F. (1966). Trawler fishing: an extreme occupation. Proc. roy. Soc. Med., 59, 405-410.

Shambaugh, P. (1935). Tar cancer of the lip in fishermen. Amer. J. Cancer, 25, 448. Abstract in J. Amer. med. Ass., 1935, 104, 2326-2329.

Syme, J. D. (1949). Some aspects of the fishing industry. Programme of the 56th Annual Conference of the Sanitary Inspectors Association, Eastbourne, pp. 39-44. John Morris (Publicity) Ltd., London.

(1966). Fish and Fish Inspection, 2nd ed., pp. 22-25. Lewis, London.

Tunstall, J. (1962). The Fishermen, 1st ed., Macgibbon and Kee, London.

White Fish Authority (1959). The White Fish Industry. Mather and Crowther, London.
(1966). Annual Report and Accounts for the year ended March 31, 1966. H.M.S.O., London.

World Health Organisation (1967). International Medical Guide for Ships, Including the Ship's Medicine Chest and the Medical Section of the International Code of Signals. World Health Organisation, Geneva.

\section{Appendix I}

\section{Informal survey of the Hull Trawler Fleet, January, 1967}

The survey continued over a six-week period, beginning on January 18, 1967. One hundred and six $(88.3 \%)$ of the 120 trawlers were seen. Eleven $(9.2 \%)$ were stern trawlers. Of the 95 conventional trawlers, 28 were diesel and 67 oil-fired. Eighteen $(16.9 \%)$ were aged 5 years or less. Twenty-five $(23.6 \%)$ were between 6 and 10 years old. Fifteen $(14 \%)$ were between 11 and 15 years old, $46(43.4 \%)$ between 16 and 20 years old, and two $(1 \cdot 1 \%)$ were over 20 years old. All were post-war trawlers. The crew accommodation was forward in $30(28.3 \%)$, amidships in $11(10.4 \%)$, and aft in $65(61.3 \%)$. The Hull trawlers came well up to the standard of the proposed Convention in respect of all but four articles (Articles 10, 12, 13, and 14) (Appendix Table).

The 11 stern trawlers, the most modern vessels, had changing rooms and laundry rooms with domestic washing machines, and seven had recreation rooms. The provision of these is not a requirement of the International Labour Organisation Convention.

\section{Appendix II}

\section{Extracts from a diary of the fishing voyage of the 'Northern Gift', May 2-21, 1964}

Day 1 Sat. 2

Sailed at 10.00 a.m. Skipper arrived at the last minute, came straight on to bridge and we were away.

Day 3 Mon. 4

Called at 6.00 a.m. as passing through the Faeroes Strait. Dark, misty, and mysterious. Islands were solid masses of rock rising straight out of the sea on each side, with little houses perched on their sides. Weather worsened on leaving Strait. Into N. Atlantic proper. Winds Mid-day Force 5. Evening Force 7.

Day 4 Tues. 5

E. Iceland. Glettinganes.

Shot first trawl about 1.00 p.m. Four baskets as result. Skipper decided no good. Steamed to N. Skagi. Shot again 11.00 p.m. Wind Force 7.

Day 5 Wed. 6

Winch broke down during the night. The trawl was torn and repaired. Third haul produced 90 baskets.

Third hand struck left hand with a marlin spike (an iron spike $1 \mathrm{ft}$. long). Penetrating wound 2 in. long entering lat. aspect of index finger and passing under the 
APPENDIX TABLE

Number of Trawlers of 106 Ships of THe Hull FleEt (IN JANUARY, 1967) NOT FUlfilling the Standard of the Proposed Instrument of the InTERnational Labour Organisation on ACCOMMODATION ON BOARD FISHING VeSSELS

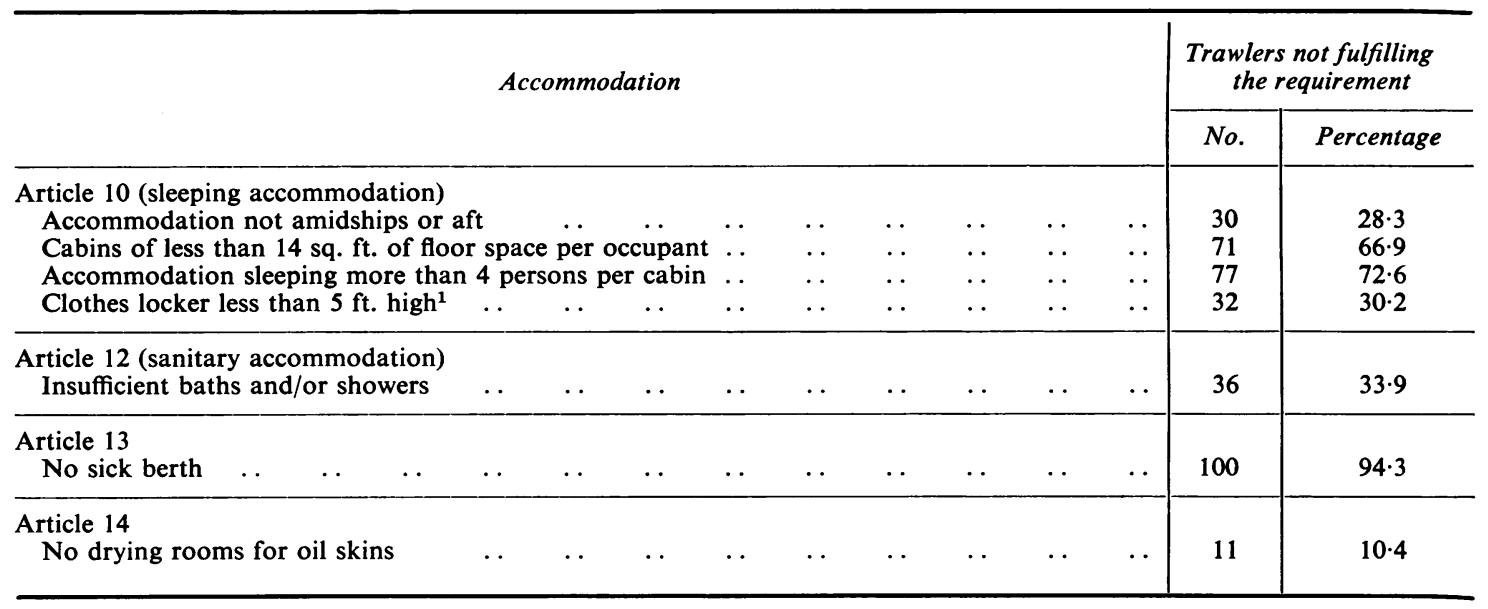

${ }^{1}$ The Accommodation of Crews (Fishermen) Convention 1966 does not specify a height but that it should be 'as commodious as practicable'.

skin over dorsum of hand to third metacarpal. Cleaned, dressed and put him on penicillin.

Deck hand trapped left hand in cabin door. Haematoma over fourth metacarpal. Both continued working. Wind E Force 7 all day.

Day 6 Thurs. 7

Same fishing ground. Weather still poor. Wind Force 7.

'Hull City' and 'Northern Jewel' (skipper's brother's ship) left us for home.

Continuous shooting and hauling except when the winch broke down. Haul, mend trawl and nets. Shoot. Gut till fish is down in hold. Rest till next haul.

Skipper informed that it is freezing with Force 8 gale at the Cape, 60 miles away. To trawl here till weather improves. Catching mostly sullock.

Third hand's hand still painful but looks and feels better. Working continuously.

Skipper has had two hours' sleep that I know of in last two days, one yesterday and one today.

Weather worsened to Force 8 in afternoon. Huge swell and waves twice height of trawler when she was in trough. At 6.00 p.m. skipper steamed east out of it to new fishing ground, while other trawlers sheltered.

\section{Day 7 Fri. 8}

On Kjolsen Bank. Winds fresh. Visibility 30 miles. Saw snow-covered mountains of Iceland for first time. Multitude of trawlers in all directions.

Third hand's hand much improved.

Call from 'Torcellon' re boy with spots. No. temp. but unwell with diarrhoea. Skipper has been giving him Castor Oil! To leave alone and give aspirin.

Debate with crew on smoking and lung cancer. Answered all their questions.
Day 8 Sat. 9

Called by skipper for radio message from other trawler. Boy better this morning but has more spots. Slight temp. in night. Spots now itching. Rx. Sod. Bic. After search returned to say none in Medicine Chest. Suggested he try the cook.

\section{Day 9 Sun. 10}

Weather has worsened (Force 8) and we have been lying off Cape since 5.00 a.m. this morning. Couldn't sleep in trying to stay in bunk.

Started fishing after breakfast in Force 6-7 gale. Continued all day N.W. of Cape. Very poor results. Mauled gear, broke steel rope before lunch. We are only ship with fish on board however.

Chief Engineer has very bad oil dermatitis of forearms and hands.

\section{Day 10 Mon. 11}

Wind Force 6-7. Snowing and snow is collecting on bridge windows but still fishing. Broken and fouled trawls today.

Noted crew's boredom. Just sitting in mess room looking at each other.

Day 11 Tues. 12

Five men have stopped smoking since talk about cancer. After tea, 1st haul had 3 bags of fish (150 baskets). Worth seeing.

Day 14 Fri. 15

Sunshine. Sea like millpond. This afternoon Iceland visible. Trawlers in V-formation. 'Northern Gift' leading the way. Marvellous sight. 


\section{Day 15 Sat. 16}

Fine but freshening. Wakened with news that we lost most of the trawl in the night and that we were now steaming for home. Skipper was turned in.

\section{Day 16 Sun. 17}

East Iceland a.m. Crew cleaning down ship. Men everywhere, washing windows, scrubbing mats and floors, polishing brasses. Going through ship from stem to stern.
Day 17 Mon. 18

Men appearing in ones and twos after baths, removal of beards, etc. Look different and almost strangers, out of gear. Heavy seas. Passed East of Faeroes p.m.

\section{Day 19 Wed 20}

11.00 p.m. Into Humber. Saw lights of Grimsby about midnight. Approaches filled with shipping. Bustling with activity. Tugs marshalling trawlers in dark. Shouting to and fro. Tremendous excitement.

Through lock gates about 1.00 a.m. Thursday, 21 st.

Received for publication March 19, 1968.

$\underline{\underline{w}}$ 